\title{
VIOLÊNCIA E CRISE DE LEGITIMIDADE: UM DIÁLOGO COM A PEÇA CORIOLANO
}

\author{
VIOLENCE AND LEGITIMACY CRISIS: A DIALOG WITH THE PLAY CORIOLANUS
}

\section{Mara Regina de Oliveira*}

\begin{abstract}
Resumo:
Este artigo parte da hipótese de que é possível desenvolver um diálogo interdisciplinar entre a obra teatral de Shakespeare e as teorias jurídicas críticas contemporâneas que estudam o poder a partir do ponto de vista interativo. Poder não é uma substância, mas uma interação que se desintegra e se constitui na relação de mando/obediência. Ele não pode ser confundido com a violência física, mas apenas com a violência simbólica. O trágico drama de Coriolano, de William Shakespeare, é o objeto de análise deste estudo.
\end{abstract}

Palavras-chave: Poder. Legitimidade. Shakespeare. Obediência. Subversão. Violência.

\begin{abstract}
:
This paper considers the hypothesis that it is possible to develop an interdisciplinary dialogue between the plays of Shakespeare and contemporary critical legal theories that study the power from an interactive point of view. Power is not a substance, but an interaction that is disintegrated and constituted in relation to command/ obedience. It cannot be identified with the physical violence, but only with the symbolic violence. The tragic drama of Coriolanus, by William Shakespeare, is the object of analysis in this study.
\end{abstract}

Keywords: Power. Legitimacy. Shakespeare. Obedience. Subversion. Violence.

Coriolanus is an odd role for me. I did it paired with Richard II, always a part I would had my eye on. There is no particular connection between the plays, except they are both about people who aspire to power and abuse it. He is one of the hardest characters to like, I think. (Ralph Fiennes, English stage actor) $)^{l}$

\footnotetext{
* Mestre e Doutora em Filosofia do Direito, pela Pontifícia Universidade Católica de São Paulo, Professora Assistente Doutora na Faculdade de Direito da mesma universidade. Professora Doutora da Faculdade de Direito da Universidade de São Paulo, onde leciona, no Curso do Pós-Graduação a disciplina "A legitimidade do poder sob a ótica do discurso jurídico e sua relação com o teatro shakespeariano.

1 CURRY, Julian. Shakespeare on stage, thirteen leading actors on thirteen key roles. London: Nick Hern Books Limited, 2010. p. 39.
} 
Introdução

Segundo Hilton Japiassu, a pesquisa interdisciplinar ocorre quando a colaboração entre várias disciplinas conduz a interações, isto é, a certa reciprocidade de intercâmbios de conteúdos. Ao final do processo interativo, cada disciplina é enriquecida, podendo gerar a criação de uma disciplina interdisciplinar. Ela não é uma associação quantitativa, pois deve conseguir incorporar os resultados de várias especialidades, fazendo a integração e a convergência depois de serem comparados e julgados. ${ }^{2} \mathrm{O}$ estudo interdisciplinar, que relaciona direito e arte, está presente na seara do enfoque teórico zetético jurídico, como forma profícua da expansão da pesquisa jurídica. Ao contrário dos estudos teóricos dogmáticos, esta forma de reflexão não se ocupa das questões práticas de decidibilidade de conflitos. Em caráter distinto, está vinculado com a ampliação crítica dos conhecimentos em torno do fenômeno jurídico, focando questões sociais, políticas, filosóficas e também estéticas. No entanto, estes enfoques acabam por se relacionar, na medida em que não é possível desenvolver uma hermenêutica dogmática prática, sem que haja uma visão do conhecimento de toda a complexidade que cerca o fenômeno jurídico. Daí a necessidade de valorizarmos um estudo interdisciplinar no seu campo temático. ${ }^{3}$

Segundo preconiza Edgar Morin, a maior contribuição, em termos epistemológicos, do século XX, foi o conhecimento dos próprios limites do conhecimento e da necessidade de fazer a convergência de diversos ensinamentos, mobilizar diversas ciências e disciplinas para enfrentar as incertezas. Os axiomas da lógica clássica foram revistos, bem como a racionalidade científica tradicional. O papel da educação não seria apenas o de transmitir informações e conhecimentos sempre mais numerosos aos alunos, mas o de promover a transformação existencial do conhecimento adquirido em sapiência, que deve ser incorporado por toda a vida. Nesta perspectiva, destaca-se a importância da cultura de humanidades, exposta nas manifestações artísticas. ${ }^{4}$

Morin considera Shakespeare um marco epistemológico, pois, desde a exposição de sua obra teatral, sabe-se que uma única obra literária alberga um infinito cultural que engloba ciência, história, religião, ética e outros saberes. É no romance, no teatro, no filme que percebemos que o racional homo sapiens é, ao mesmo tempo, indissoluvelmente, o emotivo homo demens, a existência revela a sua miséria e sua grandeza trágica, com o risco do fracasso, do erro e da loucura. No romance ou no espetáculo cinematográfico, a magia do livro ou do filme faz-nos compreender o que

2 JAPIASSU, Hilton. Interdisciplinaridade e patologia do saber. Rio de Janeiro: Imago Editora, 1976. p. 75.

3 FERRAZ JR, Tercio Sampaio. Introdução ao estudo do direito: técnica, decisão, dominação. 4. ed. São Paulo: Atlas, 2003. p. 21.

4 MORIN, Edgar. A cabeça bem feita, repensar a reforma, repensar o pensamento. Rio de Janeiro: Bertrand Brasil, 2000. p. 55-56. (cap. 4 - Aprender a viver). 
não compreendemos na vida comum, onde percebemos os outros de forma exterior, ao passo que na tela e nas páginas do livro eles surgem com todas as dimensões, subjetivas e objetivas. $^{5}$

O teatro serve de ligação entre o homo sapiens e o homo demens. Não haveria inteligência racional sem a afetividade pathos. Ela intervém no desenvolvimento da inteligência. Mas as paixões desmedidas também podem levar a perdição. Esta reflexão é muito presente na obra de Shakespeare, já que existe uma permanente complementaridade entre paixão e razão. A realidade humana é o produto de uma simbiose do racional com o vivido. O real só é real saturado de valores, que, por sua vez, são saturados de afetividade. Há uma relação antagônica e complementar entre a realidade afetiva e a racional. Assim, a eliminação da afetividade tiraria substância da realidade, reduzindo-a a equações, modelos formas. Precisamos da correção lógica, da argumentação racional, mas também de sensibilidade.

De acordo com Harold Bloom, Shakespeare inventou o humano ou a percepção estética do que ele seria. A centena de personagens que criou se reconstroem, eles assumem o domínio de si mesmos pela fala que se dá entre eles mesmos ou em relação a outros. A capacidade de se autoanalisar (autoescutar) é o caminho para a individualização. Personagens literários antes de Shakespeare são representados como relativamente imodificáveis, eles agem e morrem, mas não mudam por causa de sua relação com eles mesmos, mas por uma determinação divina. Em suas peças, encontrase presente, de forma indissolúvel, a complexa interação dialógica entre homo sapiens/ demens, expondo os problemas de nossa consciência subjetiva de forma profunda, sem maniqueísmos ou simplificações. ${ }^{6}$

As teorias críticas do direito apresentam muitas discussões que envolvem questões humanas problemáticas, vivenciadas pela reflexão interdisciplinar de forma muito impactante. Grandes temas como a diferença entre "direito", "poder", e "violência" tem uma natureza racional-afetiva profunda. É possível fazer uma convergência temática de textos e obras artísticas, mas a leitura estrutural e profunda tem de ser desenvolvida nas duas linguagens. Como exemplo, vamos mencionar uma breve análise da peça Coriolano de William Shakespeare.

Em nossa leitura interdisciplinar, Shakespeare faz uma abordagem interativa e pragmática do poder, que superou a visão teológica do Direito Divino, dominante em sua época, onde se fortaleciam as monarquias nacionais. Por intermédio de uma linguagem dramática, percebe-se que o poder não é uma substância, nem é confundido com a violência, mas um fenômeno linguístico da comunicação. Em várias peças, discute-

MORIN, Edgar. op. cit., p. 49.

6 BLOOM, Harold. The invention of the human. New York: Riverhead Books, 1999. p. 2. 
se quais seriam os pressupostos e as ações nascidas da preocupação com a organização e os interesses do Estado e a conduta dos governantes e governados que afete ou que seja afetada por tais ações ou pressupostos. Aceitando a premissa de que justamente o tempo de afirmação das monarquias nacionais é precipuamente político na Europa Ocidental.

A fim de desenvolver este diálogo entre teorias sociológicas do poder e Shakespeare, escolhemos analisar a tragédia Coriolano, que é a última das dez tragédias que Shakespeare escreveu em 1608. Inspirada na obra de Plutarco traduzida para o inglês com o título de The Lives of the Noble Grecians and Romans, trata da vida de um grande general do período republicano romano que era notório pelo desprezo que sentia pelo povo. Não obtendo o título de cônsul por isso, foi banido de Roma e só desistiu de invadir e destruir a cidade por atender a um pedido de sua mãe. A diferença entre direito, poder e violência, na obra teatral, mostra-se associada a linguagem e emerge em situação de crise de legitimidade, permitindo a localização de situações abusivas, que aparecem generalizadas ao longo da peça. Nossa análise, além do texto da peça, inclui a referência de duas performances que tivemos a chance de assistir no teatro londrino: A montagem feita pelo Almeida Theatre em 2000, dirigida por Jonathan Kent, tendo o ator Ralph Fiennes no papel de Coriolano. E a recente performance em temporada de 2013 no Donmar Warehouse, dirigida por Josie Rourke, tendo como protagonista o ator Tom Hiddleston. Também embasa as nossas reflexões, a versão fílmica, intitulada, Coriolano, dirigida por Ralph Fiennes em 2011, tendo ele mesmo no papel do protagonista. O filme tem por proposta mostrar a atualidade de Coriolano ao contrapor parte do texto clássico com um cenário de crise contemporâneo, que não é propriamente identificado. Sua leitura do texto complexo é resumida, mas visceral.

\section{O papel da afetividade no conhecimento}

No pensamento de Edgar Morin, a compreensão humana nos alcança quando sentimos e concebemos os humanos como sujeitos que têm tristezas e alegrias. Quando reconhecemos no outro os mecanismos egocêntricos de autojustificação, que estão em nós mesmos. É a partir dela que se pode lutar contra o ódio e a exclusão. Toda a percepção é uma tradução reconstrutora realizada pelo cérebro, a partir de terminais sensoriais, nenhum conhecimento pode dispensar interpretação. Cada um pode produzir a mentira para si mesmo, recorrendo a um egocentrismo justificador e a transformação do outro em bode expiatório de nossas frustrações. ${ }^{7}$

MORIN, Edgar. A cabeça bem feita, repensar a reforma, repensar o pensamento. Rio de Janeiro: Bertrand Brasil, 2000. p. 53. (cap. 4 - Aprender a viver). 
Morin destaca que, a partir do século XVIII, a racionalidade passa a ser vista como uma disposição mental que suscita um conhecimento objetivo do mundo exterior, elabora estratégias eficazes, realiza análises críticas e opõe um princípio de realidade ao princípio do desejo. Os avanços da ciência, da técnica e da economia confirmam a sua eficácia. No entanto, citando Platão e Freud, entende que especificidade racional é insuficiente porque ignora a loucura, a afetividade, o imaginário, o mitológico, o lúdico, o religioso. Menciona um interessante paradoxo: Seria irracional, louco e delirante ocultar o componente irracional, louco e delirante do humano. ${ }^{8}$

O homem se apresenta como homo sapiens, faber e economicus. No entanto, destaca Morin, o homo faber também é killer, o homo sapiens exterminou os neandertalenses que viviam na Europa desde dezenas de milhares de anos antes da chegada do sapiens. A partir dos poderes da ciência e da técnica, que trouxeram avanços materiais, lançou-se à conquista mortal do planeta, extinguindo os índios e criando a escravidão. Nota-se que a agressividade tem estado presente na história humana, em conflitos religiosos e ideológicos. Existem, algumas ilhas de bondade. ${ }^{9}$

Segundo Morin, o homem tem uma natureza ambígua, ele é ao mesmo tempo, racional e irracional, temos o que ele chama de homo sapiens-demens. Por meio de leis jurídicas e da inculcação, desde a infância, no espírito dos indivíduos, normas e interdições, a agressividade é inibida por regras de cortesia, também. Todavia, uma atitude agressiva ou uma humilhação despertam a nossa agressividade, o amor pode se transformar em ódio e romper controles. ${ }^{10}$

O tema do poder, tratado neste artigo, põe em evidência a presença do homo sapiens-demens. Elias Canetti, num instigante livro, intitulado "Massa e Poder", faz observações contundentes e originais a respeito do fenômeno do poder, enquanto algo intrinsecamente relacionado ao universo humano em geral, em seus vários aspectos. Há confluência com o pensamento de Morin, no estudo da irracionalidade humana. A partir de uma aguçada observação dos fenômenos naturais e do comportamento dos animais, mostra como as relações de poder, que os homens estabelecem entre si, são muito semelhantes com as do meio natural em que vivem, tendo, portanto, uma origem biológica. O natural e, aparentemente, inocente processo biológico da digestão, que afeta a todos os homens e lhes garante a sobrevivência, oculta uma terrível relação de poder entre dois seres, ou seja, entre o ser que "engole" e o ser que é "engolido", que se concretiza no momento em que este último perde a sua forma, ao ser incorporado àquele que o digeriu. Isto, acrescenta o Autor, faz com que cada um de nós, ainda que inconscientemente, reconheça

MORIN, Edgar. op. cit., p. 117.

MORIN, Edgar. op. cit., p. 117.

10 MORIN, Edgar. op. cit., p. 118. 
o excremento como uma espécie de prova do nosso pecado cotidiano ininterrupto, que nos garante a manutenção da vida. Por isso, ele causa vergonha a todos nós, fazendo com que seja conveniente nos livrar dele de uma forma isolada. ${ }^{11}$ Canetti afirma:

Os excrementos que restam no final estão carregados
com todas as nossas culpas de sangue. Por eles podemos
reconhecer que cometemos assassinatos. São a totalidade
concentrada dos indícios existentes contra nós mesmos.
Exatamente como nossos pecados cotidianos, contínuos e
jamais interrompidos, eles fedem e clamam aos céus. Chama
a atenção o modo como nos desfazemos deles. Desfazemo-
nos deles em lugares próprios, destinados unicamente a este
fim; o mais privado de todos os momentos é o da excreção;
ficamos realmente a sós com nossos excrementos. É claro
que nos envergonhamos deles. Eles são o sinal antiquíssimo
daquele processo que ocorre num plano oculto e que sem
este sinal permaneceria oculta. ${ }^{12}$

Fazendo uma analogia com as relações políticas, ele diz que os homens, no momento em que pretendem ser superiores, conscientemente, não hesitam em rebaixar seus semelhantes, surrupiando-lhes os direitos e a capacidade de resistir a fim de tornálos impotentes, como se eles realmente fossem suas "presas". Este "consumo" muitas vezes é feito de forma sutil, de modo que a "incorporação" não é percebida enquanto tal. Todavia, no momento em que estas "presas" não tiverem uma utilidade, elas serão facilmente postas de lado. Estas relações de poder, que degradam os homens a condição de "animais criados para serem abatidos", na maioria das vezes, permanecem ocultas aos olhos da sociedade, que pode, ingenuamente, pensar que está sendo "alimentada". Afinal, diz Canetti, "bastante fácil é, pois, não enxergar o cerne de tais processos, uma vez que o homem também mantém animais que não mata de imediato, ou não mata nunca, pois lhe são mais úteis para outras coisas". ${ }^{13}$

O Autor também nos chama a atenção para o fato do fenômeno do poder ser desenvolvido às escondidas e estar relacionado com a ideia de ocultação. Deste modo, também reconhece a importância da utilização de "máscaras" como meio de dissimulação e os "perigos" do súbito desmascaramento. Temos, segundo ele, um curioso "jogo" de máscaras, onde um tenta combater a dissimulação do inimigo com a própria dissimulação. Vencerá aquele que for mais veloz na retirada das máscaras, pois o “detentor do poder”,

CANETTI, Elias. Massa e poder. Brasília: Editora Universidade de Brasília, 1983. p. 209.

CANETTI, Elias. op. cit., p. 209.

CANETTI, Elias. op. cit., p. 208-209. 
bem consciente da sua constante simulação, somente pode esperar a mesma coisa por parte de seus semelhantes. ${ }^{14}$

Além de permanecer oculto, podemos dizer que o poder tem que ser mais genérico e mais vasto do que a força, que está mais próxima e presente, na medida em que exerce um poder coercitivo imediato. $\mathrm{O}$ ato de agarrar a presa constitui um ato de força, que pode transformar-se em poder, caso dure bastante. Assim, a força precede a relação de poder, a qual é mais complexa e exige mais habilidade e paciência. Quando o gato subitamente captura o rato, ele subjuga-o pela força, mantendo-o preso. Todavia, a situação se altera, no momento em que ele começa a brincar com o roedor. Ele o solta e permite que se locomova livrando-o da coação da força. No entanto, este "espaço concedido" não constitui uma liberdade real para o rato, na medida em que o felino dispõe do poder de alcançá-lo quando desejar. O espaço delineado pela sombra do gato, os instantes de esperança de sobrevivência que concede ao rato, bem como, a estrita vigilância, direcionada a uma possível destruição do rato, constituem o corpo do poder. Além de estar oculto, ele está ligado à ideia de controle, com interesse destrutivo, que exige uma ampliação do espaço e do tempo. Neste sentido, a prisão apareceria como um modelo de poder, que teria surgido a partir da ampliação da boca. ${ }^{15}$

Também em confluência com Morin, citamos o pensamento de Zigmunt Bauman. Para este pensador o mal está ligado à irracionalidade do homem. Por isto a pergunta o que é o mal? é irrespondível, porque tendemos a chamar de mal algum tipo de iniquidade que não podemos entender nem articular claramente, muito menos explicar a sua presença de modo satisfatório. Podemos dizer que é o crime tendo em vista um código jurídico que o criminoso infringe. ${ }^{16}$

Podemos dizer que o mal é um pecado porque temos uma lista de mandamentos cuja violação torna os praticantes pecadores. Todavia, recorremos à ideia de mal quando não podemos apontar que regra foi quebrada ou contornada pela ocorrência de ato para o qual procuramos um nome adequado. A razão é um atributo permanente e universal dos seres humanos, mas ela se torna impotente quando se trata de inserir o mal na ordem do inteligível. ${ }^{17}$

Os filósofos modernos acreditavam que as mãos humanas, uma vez equipadas com extensões cientificamente planejadas e tecnologicamente fornecidas, chegariam mais longe. $\mathrm{O}$ número de males cairia. A esperança de que a racionalidade colocasse a humanidade longe da natureza cruel não foi bem sucedida. Os males produzidos por seres

\footnotetext{
14 CANETTI, Elias. op. cit., p. 284.

15 CANETTI, Elias. op. cit., p. 284.

16 BAUMAN, Zigmunt. Medo líquido. Rio de Janeiro: Zahar, 2008. p. 74.

17 BAUMAN, Zigmunt. op. cit., p. 75-76.
} 
humanos são tão inesperados como os seus predecessores/sucessores naturais. Bauman refere-se explicitamente ao exemplo histórico de Auschwitz. ${ }^{18}$ Nas palavras do autor:

Os males ganham força e infiltram-se de modo gradual, em silêncio, por estágios aparentemente inofensivos, como uma corrente subterrânea que se dilata e se amplia antes de emergir de modo súbito e impetuoso, tal como fazem as catástrofes naturais.

Antes de Auschwitz não sabíamos como o mal moral pode ser transformado em natural, como nem só monstros cometem crimes monstruosos. O terrível é saber que qualquer um de nós poderia ter ficado de sentinela em Auschwitz. ${ }^{19}$

Numa perspectiva psicanalítico-marxista semelhante, Herbert Marcuse destaca que o progresso técnico (domínio da natureza) e quantitativo se opõe ao conceito qualitativo de progresso, ligado à ideia de liberdade da moralidade, e na extinção da escravidão, do arbítrio, da opressão e do sofrimento. Não é evidente que o progresso técnico leve automaticamente ao progresso humanitário, este cada vez mais se acha relegado ao terreno da utopia. O trabalho se torna o trabalho alienado, ele passa a ser o próprio conteúdo da vida, que só é vivida como trabalho. ${ }^{20}$

Marcuse destaca, numa leitura freudiana, que nem a felicidade, nem a liberdade são produtos da civilização, pois são com ela incompatíveis. Esta está fundada na opressão, no recalque das pulsões sensuais, sendo impensável sem uma transformação repressiva das pulsões. Condição fundamental para o desenvolver de um trabalho penoso. Haveria uma oposição entre o princípio do prazer x princípio da realidade. ${ }^{21}$

O organismo tem duas pulsões fundamentais, Eros e pulsão para a morte, regressão ao estado pré-natal. O resultado psíquico da dominação do princípio da realidade começa com a proibição do incesto, à superação do complexo de Édipo e à interiorização da autoridade paterna. A energia erótica se transforma em energia para o trabalho não prazeroso. $^{22}$

Segundo Marcuse, a repressão das pulsões não resulta de uma necessidade natural, mas decorre de um interesse de dominação despótica, constituído historicamente. Ele se tornaria supérfluo na medida em que a civilização se aproximasse de um estágio em que a eliminação de um modo de vida que força a repressão das pulsões se torna

18 BAUMAN, Zigmunt. op. cit., 2008, p. 80.

19 BAUMAN, Zigmunt. op. cit., 2008, p. 86.

20 MARCUSE, Herbert. A noção de progresso à luz da psicanálise. In: MARCUSE, Herbert. Cultura $e$ psicanálise. Tradução de Wolfgang Leo Maar, Robespierre de Oliveira e Isabel Loureiro. Rio de Janeiro: Paz e Terra, 2004. p. 103.

21 Id. Ibid., p. 106.

22 MARCUSE, Herbert. op. cit., p. 113. 
possibilidade realizável. Precisaríamos de um princípio da realidade qualitativamente diferente. Hipótese da automação total. Sua postura ligada aos ideais marxistas pressupõe uma possibilidade de superação desta repressão destrutiva. ${ }^{23}$

Para Morin, em consonância de raciocínio com Bauman e Marcuse, quando há a ausência dos fatores de regulação: o do mundo exterior (princípio da realidade), o mental da racionalidade, o social e cultural que institui barreiras e tabus contra a agressividade e a violência, a demência pode quebrar a resistência do mundo, impondolhe destruição. A racionalidade pode servir à pulsão destrutiva, de forma clara. A cultura pode colocar-se a serviço da guerra. ${ }^{24}$

Esta irracionalidade é universal para Morin. Os germes de toda loucura estão escondidos em cada indivíduo, ou em cada sociedade, e negá-lo pode ser ainda mais perigoso, por potencializar o nosso viés destrutivo. Excesso de coerência transformar a racionalidade em racionalização delirante, que pode levar a formas frias de loucura. Não existe nenhum dispositivo cerebral intrínseco que distinga a alucinação da percepção, o imaginário, do real, o subjetivo do objetivo. ${ }^{25}$

Os controles racionais não são soberanos e nos remetem a uma relação instável no cérebro. A racionalidade é apenas uma instância concorrente e antagônica da afetividade e da pulsão. A agressividade delirante pode servir-se da lógica e da racionalidade técnica para justificar seus empreendimentos. Complexidade do cérebro é a sua força e a sua fragilidade, a loucura e a genialidade inventiva podem estar próximas. ${ }^{26}$

O ponto alto da reflexão de Morin aparece quando destaca que a afetividade serviria de ligação entre o homo sapiens e o homo demens, desempenhando um papel cognitivo relevante. Não haveria inteligência racional sem a afetividade - pathos. Ela intervém no desenvolvimento da inteligência. Mas as paixões também podem levar a perdição. Há complementaridade entre paixão e razão. A realidade humana é o produto de uma simbiose do racional com o vivido. ${ }^{27}$

O real só se constitui como tal se for saturado de valores, que, por sua vez, são saturados de afetividade. Há uma relação antagônica e, ao mesmo tempo, complementar entre a realidade afetiva e a racional. A eliminação da afetividade tiraria substância da realidade, reduzindo-a a equações, modelos formas. Morin adverte que precisamos da correção lógica, da argumentação racional, mas também de sensibilidade. ${ }^{28} \mathrm{~A}$ afetividade

\footnotetext{
23 MARCUSE, Herbert. op. cit., p. 115.

24 MARCUSE, Herbert. op. cit., p. 119.

25 MARCUSE, Herbert. op. cit., p. 119.

26 MORIN, Edgar. A cabeça bem feita, repensar a reforma, repensar o pensamento. Rio de Janeiro: Bertrand Brasil, 2000. p. 120. (cap. - 4 Aprender a viver).

27 MORIN, Edgar. op. cit., p. 121.

28 MORIN, Edgar. op. cit., p. 122.
} 
invade todas as manifestações do sapiens-demens, as quais também a invadem. Se ela for delirante, pode levar ao crime, ao ódio. Ela toma a forma de uma inquietude, de ansiedade, de aflição, já presentes no mundo animal e que, no mundo humano, aprofunda-se em angústia de morte como a angústia da existência. ${ }^{29}$ Segundo Morin:

\begin{abstract}
A medida do mundo se reflete na medida do homem. Cada relação com o mundo realiza certo sentido de verdade, que o homem não domina, mas que intervém na experiência, assegurando-lhe a comunicação entre ele e o mundo ou consigo mesmo. Cada atitude humana em face do mundo, torna-se objeto de reflexão e engendra uma filosofia. Como há várias relações com o mundo, cada qual com sua verdade própria, resulta o aparecimento de várias filosofias, nenhuma delas possuindo a verdade total. ${ }^{30}$
\end{abstract}

Na visão do Autor, a racionalidade é raramente hegemônica, e, com frequência, é encoberta, contaminada ou mesmo manipulada. Em contrapartida, a afetividade é onipresente. A morte seria o lugar do grande encontro da racionalidade, a afetividade e do mito. O criminoso, o louco, o santo, o profeta, o gênio, escapam, cada um do seu jeito, rompem as normas da racionalidade. ${ }^{31}$

As artes têm importância cognitiva porque promovem a confluência de sapiens e demens, de forma construtiva. A possibilidade do gênio vem do fato do ser humano não ser prisioneiro do real, da lógica, da cultura, da sociedade. Ele surge na brecha do incontrolável onde ronda a loucura. O pensamento, a ciência, as artes, foram irrigados pelas forças profundas da afetividade. A criação nasce do encontro do caos das profundezas psicoafetivas com a pequena chama da consciência. ${ }^{32}$

Trata-se de uma ideia simplista supor que homo é essencialmente sapiens e faber. Morin afirma:

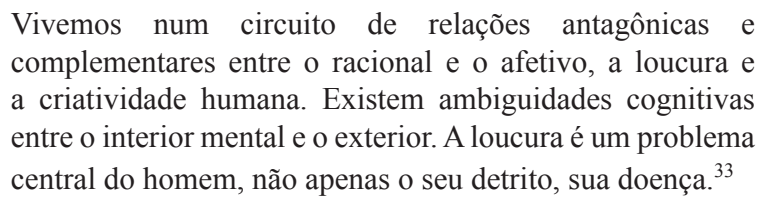

A seguir veremos como a obra de Shakespeare articula, no plano artístico, a confluência homo sapiens-demens.

\footnotetext{
29 MORIN, Edgar. A cabeça bem feita, repensar a reforma, repensar o pensamento. Rio de Janeiro: Bertrand Brasil, 2000. p. 123.

30 MORIN, Edgar. op. cit., p. 171. (cap. - 4 Aprender a viver).

31 MORIN, Edgar. op. cit., p. 126.

32 MORIN, Edgar. op. cit., p. 126.

33 MORIN, Edgar. op. cit., p. 128.
} 
2. Shakespeare e a invenção do humano: a ampliação de nossa consciência subjetiva na compreensão do tema da legitimidade jurídico-política

O pensamento de Harold Bloom, a nosso ver, aprofunda a tese defendida por Morin em torno da possibilidade de Shakespeare viabilizar a ampliação de nossa consciência subjetiva. Segundo o Autor, os personagens literários, antes de Shakespeare, são representados como relativamente imodificáveis, eles agem e morrem, mas não mudam por causa de sua relação com eles mesmos, mas por uma determinação divina. Em Shakespeare, os personagens se reconstroem, eles assumem o domínio de si mesmos pela fala que se dá entre eles mesmos ou em relação a outros. A capacidade de se autoanalisar (auto escutar) é o caminho para a individualização. Ele criou mais de uma centena de diferentes vozes/personagens.

As peças permanecem além do limite das aquisições humanas, do ponto de vista cognitivo, moral e espiritual. Elas ficam além do que nossa mente pode alcançar, nós não conseguimos apanhá-las de forma total e definitiva. Shakespeare irá nos explicar, ao longo das peças, porque em parte ele nos inventou. Os personagens principais espelham novos modos de consciência. Segundo Bloom, depois de Jesus, Hamlet é a mais citada figura na consciência ocidental. Ele não pode ser reduzido a um papel para um ator, pois há mais Hamlets do que atores para representá-los. ${ }^{34}$

As peças penetrariam na nossa consciência e a analisariam. Cita a importância do crítico literário Samuel Johnson. Para ele, a essência da poesia foi a invenção, como um processo de descoberta, nós possuímos tudo de Shakespeare. Ele nos ensinou a entender a natureza humana. Imitações (mimeses) produzem dor ou prazer, não porque elas são confundidas com a realidade, mas porque elas trazem realidade para as mentes. $^{35}$

Na reflexão de Bloom, o que Shakespeare inventa são modos de representar mudanças humanas, alterações não apenas causadas pelas falhas ou pela decadência, mas também pela vontade humana, e suas vulnerabilidades temporais. Ele traz vida para a mente, tornando-nos conscientes de coisas que não perceberíamos sem ele. Ele imita a natureza humana essencial, a qual é universal e não um fenômeno social. Ele implicitamente teria contestado uma transcendente concepção de realidade. ${ }^{36}$

Neste sentido, apenas a Bíblia teria o alcance de Shakespeare (um Deus mortal), ainda que a sua visão seja secular. O que eles têm em comum é o seu universalismo, ele está em todos os contextos (aurora boreal é visível aonde a maioria de nós nunca irá,

\footnotetext{
34 BLOOM, Harold. The invention of the human. New York: Riverhead Books, 1999. p. 2.

35 BLOOM, Harold. op. cit., p. 2.

36 BLOOM, Harold. op. cit., p. 3.
} 
livrarias, teatros e cinemas não podem contê-lo). Ele não sabe por que isto acontece, mas como isto continua. A superioridade de Hamlet e de Falstaff é cognitiva, linguística e imaginativa, são personalidades carismáticas. ${ }^{37}$

A ideia de um indivíduo, como agente moral, tem muitas fontes, por exemplo, o pensamento de Homero, Platão, Sófocles, a Bíblia, Dante, Kant. Mas, na visão de Bloom, a personalidade é uma invenção shakespeariana e seria a causa de sua permanente capacidade de persuadir. Aquilo que nós mesmos valorizamos e deploramos em nossa personalidade são heranças dos personagens de Shakespeare. Nesta perspectiva, entendemos que esta invenção do humano a que se refere Bloom pode ser relacionada com a percepção estética do homo demens e o de todo o seu universo afetivo irracional a que se refere Morin. ${ }^{38}$

Não podemos saber sobre o ceticismo de Shakespeare sobre o valor da personalidade. Para Hamlet, o self é um abismo, o caos do nada. Bloom levanta questões contundentes: por que seus personagens parecem tão reais? Como ele constrói esta ilusão de forma tão persuasiva? ${ }^{39}$ Em reposta ele mesmo afirma: Shakespeare nos fez teatrais, ainda que nunca tenhamos lido ou visto uma peça. A vida tornou-se uma irrealidade natural. Ele inventou os nossos sentimentos, foi além de nos psicologizar. ${ }^{40}$

Nossa educação em várias partes do mundo tem sido shakespeariana, não apenas em países de língua inglesa. As ideologias que estão na moda são caricaturas de energias shakespearianas. Ele seria um autor que celebraria a vida, além das tragédias, ou ele seria um niilista?

A nosso ver, Shakespeare encarna, por conta de seus complexos personagens, a exposição profunda e ambígua do homo sapiens-demens. Bloom ficaria feliz se ele sustentasse uma transcendência secular, uma visão do sublime, mas ele reconhece que o niilismo assombra quase todas as peças, mesmo as comédias. $\mathrm{O}$ bardo parece muito sábio para acreditar em alguma coisa.

Na reflexão do Autor, Shakespeare tem sido universalmente julgado para ser o mais adequado representante do universo do que qualquer outro antes dele ou depois. Este julgamento tem sido dominante desde a metade do século XVIII, nós mantemos o retorno para Shakespeare porque nós precisamos dele, ninguém nos deu tanto sobre o universo, ele foi o mais original e o melhor escritor que já conhecemos. Ele não seria ocidental, mas universal, ele, e não Freud, seria o nosso psicanalista, por expor, sem pudores racionalistas ilusórios, o lado destrutivo e irracional de nossa personalidade. ${ }^{41}$

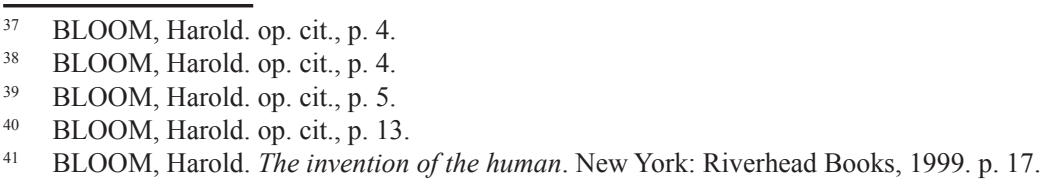


Bloom recusa proceder a uma leitura estritamente histórica e social da obra do bardo, afirma, de forma instigante, corroborando a sua universalidade atemporal:

Se Shakespeare fosse apenas um produto de um processo social, talvez qualquer social produto pareceria bom como outro. Este é o erro político por ideias acadêmicas da moda. Quem ao lado de Shakespeare continua a informar uma autêntica ideia do humano? Se Shakespeare tivesse morrido cedo, nossas ideias seriam diferentes porque eram do bardo antes de ser nossas. Ele tem mantido o status de secular bíblia nos dois últimos séculos. ${ }^{42}$

Shakespeare é uma possessão internacional, transcendendo nações, línguas e profissões. Ele é único na cultura e não apenas no mundo teatral. O Shakespeare americano não é o Shakespeare britânico, nem o japonês, nem o norueguês, porém Bloom acredita poder reconhecer algo que é realmente Shakespeare e que sobrevive sua bem sucedida migração de um país para outro. ${ }^{43}$

O propósito deste trabalho é estudar o tema do poder, relacionado à peça Coriolano, tendo vista esta questão de legitimidade, que trata o tema de forma complexa e instigante. Na esteira do proposto por Morin, no próximo item deste trabalho, desenvolveremos uma análise de teorias pragmáticas da comunicação normativa, que evidenciam a relação existente entre direito e poder e suas implicações com o tema da legitimidade. Vamos utilizar, como referência complementar ao estudo da peça, o pensamento de Bárbara Heliodora, no campo da teoria crítica literária, pois a autora é considerada uma das maiores estudiosas de Shakespeare no Brasil. Veremos como a análise da peça possibilitará uma ampliação da nossa consciência subjetiva sobre o tema, superando a visão estritamente racional presente nas teorias dogmáticas jurídicas. Nãosó a peça pode dialogar, em termos afetivos/estéticos, aquilo que é tratado, em termos teóricos e racionais, mas também pode propor questões que irão além deste plano, de forma aberta e instigante.

3. A noção pragmática de poder e a crise de legitimidade jurídico-política

Antes de iniciarmos propriamente o exame da obra shakespeariana, desenvolveremos um estudo preliminar sobre a relação existente entre abuso de poder e direito, do ponto de vista interativo. Faremos uma análise da pragmática jurídica como

\footnotetext{
$42 \quad$ BLOOM, Harold. op. cit., p. 716.
}

43 BLOOM, Harold. op. cit., p. 725. 
um tipo de teoria jurídica crítica que permite uma aproximação intertextual exemplar com o universo shakespeariano.

As teorias dogmáticas tradicionais têm uma visão substancial e racionalista da ideia de poder e têm a pretensão de torna-lo uma "substância ética", pertencente unicamente ao Estado soberano, desvinculada das relações de força que compõem a sociedade. Transformam a questão da obediência e da própria legitimidade numa premissa inquestionável, favorecendo a crença nas instituições políticas para que permaneçam como um símbolo ideal aos olhos da sociedade. Partindo destes pressupostos, lembramo-nos do instigante pensamento de Tercio Sampaio Ferraz Jr., especialmente no que ele se refere à chamada "pragmática jurídica", a qual, a nosso ver, trata com bastante originalidade e perspicácia a relação existente entre direito, poder, controle e força. Se o poder não se confunde com a força física, mas é controle da ação dos sujeitos, como exercício de influência sobre outros, não há como escapar da análise do processo comunicativo em que se estabelecem as interações humanas, que é altamente reflexivo. ${ }^{44}$

Nesta abordagem pragmática, a comunicação visa o mútuo entendimento. É considerada racional na medida em que o chamado "dever de prova", ou seja, a possibilidade do emissor fundamentar o que diz, cabe a ele próprio e é controlada pelo receptor. Nas palavras do próprio autor, "o discurso racional é aquele que presta contas, que fundamenta o que diz em relação à exigência crítica do ouvinte, para o qual está sempre aberto". ${ }^{45}$ Esta estrutura racional é, em princípio, dialógica e altamente reflexiva, enquanto o exercício da crítica puder ser ilimitado. Todavia, existe outra regra da comunicação que afirma que o receptor pode aceitar certo conteúdo da mensagem como evidente ou verdadeiro e deixar de lado o seu potencial exercício de crítica. Neste caso, o discurso teria uma estrutura monológica, relacionada à possibilidade de sua axiomatização. De fato, os discursos racionais são compostos a partir destas duas estruturas, que, no decorrer da interação, acabam por se integrar.

Ademais, é importante ressaltar que o emissor pode discutir "com" o receptor ou "contra" o receptor. No primeiro caso, temos a homologia, a relação é simétrica e de cooperação. No segundo, temos a heterologia, a relação é desigual, é partidária. Nos discursos heterológicos não existe espaço para o consenso verdadeiro, mas apenas para a persuasão. Por isso, apesar de existirem momentos monológicos, a estrutura dialógica é a que prevalece, sendo apenas interrompida pela decisão dogmática. O discurso jurídico, devido ao seu caráter decisório, constitui um exemplo desta segunda alternativa, por estar

44 FERRAZ JR., Tercio Sampaio. Direito, retórica e comunicação: subsídios para uma pragmática do discurso jurídico. São Paulo: Saraiva, 1973.

45 FERRAZ JR., Tercio Sampaio. Direito, retórica e comunicação: subsídios para uma pragmática do discurso jurídico. São Paulo: Saraiva, 1973. p. 109. 
intimamente relacionado como a ideia de poder como controle comunicativo, exposto na chamada "situação comunicativa normativa". A situação comunicativa normativa apresenta peculiaridades em relação às demais formas de comunicação. Ela depende de uma "dogmatização contra fática" (inversão do ônus da prova que, ao invés de pertencer ao emissor, passa para o receptor) inicial da supremacia do chamado "editor normativo", que se põe como autoridade (cometimento da norma) para exigir certas condutas (relato ou conteúdo da norma) dos endereçados sociais, visando uma possível decisão de conflitos. Todavia, a estrutura monológica, não questionadora do discurso que impõe a relação de autoridade, ao contrário dos demais, não se baseia em axiomas que não são questionados por serem aceitos como verdadeiros por aqueles que se comunicam. Ou seja, ela não torna a questão da obediência uma verdade inquestionável, do ponto de vista semântico, ela apenas a coloca fora de discussão por uma decisão arbitrária. Afinal, todo e qualquer dogma "impõe uma verdade sobre algo que, de fato, continua duvidoso". ${ }^{46}$

Nesta perspectiva, esta supremacia não se torna, de fato, inquestionável e depende de uma complexa institucionalização no âmbito social da própria relação de autoridade, que deve neutralizar o dissenso e as possíveis reações sociais contrárias. É neste ponto que podemos identificar, com clareza, a relação existente entre direito, poder e comunicação, na medida em que a relação de autoridade não preexiste à própria interação, pois ela se constitui propriamente durante o processo interativo. Ela existe não só a partir de uma pretensão do editor normativo de impor uma relação complementar, mas na medida em que o sujeito também estiver disposto a se colocar nesta condição subalterna. O poder não está unicamente nas mãos da autoridade, não é um “objeto que ela detém”, portanto. Ele atravessa e ao mesmo constitui a própria relação autoridade/sujeito. ${ }^{47}$

Partindo de uma associação da pragmática de Tercio com a teoria do poder de Niklas Luhmann, vemos que tanto o relato quanto o cometimento das mensagens normativas implicam em relações de poder. Estas relações de poder não podem ser identificadas com a violência física, pois são entendidas como controle de seletividade do editor normativo em relação aos endereçados sociais. Como a relação de poder é complementar, ela passa a ser um elemento constitutivo da relação enquanto uma alternativa a evitar. Ela também mostra que a alternativa emprego da força física, também pode ser menos vantajosa para um dos integrantes da relação, principalmente para os sujeitos. Se ela for aplicada, concretamente, pode constituir um ponto culminante da relação, onde um poderá vencer e outro, em consequência, perder. Ela acrescenta um

46 FERRAZ JR., Tercio Sampaio. Introdução ao estudo do direito: técnica, decisão, dominação. 4. ed. São Paulo: Atlas, 2003. p. 43.

47 FERRAZ JR., Tercio Sampaio. Direito, retórica e comunicação: subsídios para uma pragmática do discurso jurídico. São Paulo: Saraiva, 1973. p. 109. 
novo esquematismo binário para a relação: "o forte e o fraco". A força é colocada no início da relação, a qual se desenvolve graças à seleção de regras que a separam dele, procedendo de uma espécie de "racionalidade". Ela passa a ser uma opção que deve ser evitada no presente, justamente porque se coloca como a uma possibilidade de uma ocorrência futura. Esta temporalização da combinatória forte/fraco coloca a força como uma condição necessária à gênese do poder, mas não do seu controle efetivo. Seu uso concreto vence uma luta, mas paga o preço de extinguir a relação de poder. ${ }^{48}$

Neste sentido, a complementaridade do editor normativo é garantida pela institucionalização do controle da seletividade das reações dos endereçados sociais que identificam as normas estatais como sendo juridicamente válidas em detrimento das demais. Por isso, é extremamente importante que ele leve em conta as reações dos chamados endereçados sociais, que podem confirmar, rejeitar ou desconfirmar a mensagem normativa. Tanto a confirmação (licitude) como a rejeição (ilicitude) reconhece e aceita o cometimento metacomplementar da norma jurídica. ${ }^{49}$

A trivial possibilidade de haver reações desconfirmadoras torna inevitável o confronto entre direito e poder, visto que elas constituem uma situação-limite em que os endereçados sociais deixam de assumir a relação complementar estabelecida no cometimento das normas jurídicas, não mais reconhecendo a condição de sujeitos da relação. Nesta situação, os endereçados sociais eliminam o controle de seletividade que o editor normativo tenta realizar. Este tem uma expectativa predeterminada de que a relação de autoridade, que ele estabelece, seja vista como uma estrutura de motivação da seletividade do endereçado que, de fato, passa a possuir duas alternativas apenas: confirmar ou rejeitar a mensagem. Aquele que desconfirma a norma desilude totalmente esta expectativa, pois age como se a autoridade, e os atos de coação que ela determina, não existissem. Trata-se de uma estratégia de desafio ao aspecto cometimento de suas normas. ${ }^{50}$

A desconfirmação pragmática faz com que o editor perca, pelo menos momentaneamente, o seu controle sobre a seletividade dos endereçados. Se for bemsucedida, ela pode criar uma nova relação de poder, uma nova cadeia normativa. Nesta, o sujeito receptor das mensagens normativas estatais passa a ser autoridade emissora de novas mensagens normativas, sustentadas por uma nova norma-origem, que é imperativa, tem poder de mando e pode ser calibrada, justificada, em termos ideológicos. Assim, ela deve ser neutralizada pela autoridade que, a todo custo, tentará se imunizar contra ela,

48 LUHMANN, Niklas. Poder. Brasília: Universidade de Brasília, 1985.

49 FERRAZ JR., Tercio Sampaio. Direito, retórica e comunicação: subsídios para uma pragmática do discurso jurídico. São Paulo: Saraiva, 1973. p. 107.

50 OLIVEIRA, Mara Regina de. O Desafio à autoridade da lei: a relação existente entre poder, obediência e subversão. Rio de Janeiro: Corifeu, 2006. p. 104. 
ao desconfirmar a reação desconfirmadora, transformando-a em uma simples rejeição, que pode ser enquadrada como comportamento ilícito, por ela controlado. Neste caso, predomina a regra de calibração do princípio da legalidade. ${ }^{51}$

As reações desconfirmadoras emergem no momento que a legitimidade da relação de poder está enfraquecida. A legitimidade está ligada, justamente, à imposição de certas significações e ao desconhecimento, por parte dos endereçados sociais, das relações de força entre grupos que compõem a sociedade, que constituem a chamada violência simbólica. O poder será considerado legítimo enquanto o seu exercício de violência simbólica for dissimulado e desconhecido pelos endereçados sociais, de modo que ele possa influenciar comportamentos por meio sua liderança, reputação e autoridade, os quais devem se combinar de forma congruente. Uma vez que o arbítrio social, em torno das relações de força, torna-se evidente, a legitimidade fica comprometida.

A influência por autoridade é necessária para que a constituição do esquematismo jurídico/antijurídico se imponha de modo contra fático e se generalize apesar da passagem do tempo. Embora haja desilusão da expectativa, o sujeito ainda a mantém, possibilitando a jurisfação do poder. Ela sempre dissimula as relações de força, que estão em sua base, agregando sua própria força simbólica às mesmas relações, por meio de normas que passam a regular o uso da violência. Neste sentido, vimos que ela só reconhece a confirmação e a rejeição de suas mensagens. Já a influência por reputação atua mais diretamente no relato das normas, pois neutraliza os conteúdos normativos e possibilita sua assimilação acrítica pelos sujeitos, em termos de valores ideológicos. Por fim, a influência através da liderança neutraliza as diferenças entre a autoridade e os sujeitos, manipulando a escassez de consenso e institucionalizando a relação metacomplementar normativa. Aqui ganham relevo todos os procedimentos institucionais legislativos, executivos e judiciais, bem como os mecanismos midiáticos de propaganda. $\mathrm{Na}$ prática, estas três generalizações devem se combinar a fim de se fortalecerem, mutuamente. Todavia, em situações disfuncionais, elas perdem o seu caráter dissimulador. Nas chamadas situações comunicativas abusivas, a força física passa a ser a base explícita do poder, podendo provocar a sua destruição, como mecanismo de influência e controle. ${ }^{52}$ A seguir, entraremos na análise específica do problema do abuso de poder na interação comunicativa.

O exercício da violência simbólica corre risco de tornar-se transparente e comprometer a legitimidade do poder, em situações comunicativas normativas defeituosas

51 OLIVEIRA, Mara Regina de. O Desafio à autoridade da lei: a relação existente entre poder, obediência e subversão. Rio de Janeiro: Corifeu, 2006. p. 120 a 122.

52 FERRAZ JR., Tercio Sampaio. Estudos de Filosofia do Direito: reflexões sobre o poder, a liberdade, a justiça e o direito. São Paulo: Atlas, 2002. p. 260 a 263. 
onde ocorrem abusos na comunicação por parte do editor normativo, em que ele elimina a própria possibilidade de seleção do sujeito, "coagindo-o" e o eliminando enquanto tal. Neste caso, a percepção da injustiça e a possível "revogação" da autoridade podem ocorrer. Por quê?

Em um ensaio bastante instigante, intitulado "O discurso sobre a justiça", o problema da justiça, na comunicação normativa, é recolocado por Tercio Sampaio Ferraz. O problema da justiça, diz o autor, está relacionado com a possibilidade de haver refutação de mensagens defeituosas, que pode ocorrer com os enunciados normativos. Quando um ou mais endereçados sociais afirmam que uma norma é injusta, esta reação implica em desconhecer ou ignorar a autoridade do emissor normativo. Esta refutação, de fato, significa numa revogação, ou seja, num outro ato normativo que a "revoga" por declarar a sua autoridade ignorável, ainda que de uma forma diferente da revogação da validade de uma norma feita através de outra. ${ }^{53}$

Estes defeitos, que implicam em condições de abuso, aparecem no cometimento normativo, ou seja, ocorrem quando a relação de autoridade também comunica uma perversão do ato de falar. A emissão de uma mensagem normativa, como vimos, pressupõe certas condições que garantem o exercício de autoridade do emissor normativo, que não pode eliminar a condição de sujeito do próprio endereçado social. Desde que exista uma mensagem normativa, onde a autoridade anule o próprio sujeito, de modo a destruir o sentido unificador de o seu próprio existir, afirmaremos que houve um "abuso das condições de exercício potestativo da autoridade. "Esta mensagem será “defeituosa”, embora possa ser juridicamente válida. Não pode haver exercício do poder na comunicação normativa se houver aniquilamento do sujeito. ${ }^{54}$

$\mathrm{O}$ defeito ocorre na medida em que o discurso da autoridade elimina a complementaridade, na medida em que substitui os dois discursos distintos (autoridade/ sujeito) por único discurso em que só ela comunica. Um discurso que não chega a ser propriamente homólogo, na medida em que constitui uma perversão da própria homologia. Como no exemplo citado: "reconheçamos que a autoria do delito não foi provada, mas deve-se reconhecer que o não acatamento da sentença destruirá a autoridade." Esta fórmula não neutraliza o discurso desconfirmador do sujeito, mas o próprio sujeito, na medida em cometendo ou não o crime ele será condenado. A relação complementar é rompida porque o emissor age como se o discurso fosse único. A desconfirmação, por parte do editor, só pode ser dirigida como uma resposta a uma reação desconfirmadora do sujeito,

53 FERRAZ JR., Tercio Sampaio. Estudos de Filosofia do Direito: reflexões sobre o poder, a liberdade, a justiça e o direito. São Paulo: Atlas, 2002. p. 268.

54 FERRAZ JR., Tercio Sampaio. Estudos de Filosofia do Direito: reflexões sobre o poder, a liberdade, a justiça e o direito. São Paulo: Atlas, 2002. p. 269. 
que visa transformá-la em simples rejeição. A desconfirmação da autoridade não pode alcançar aqueles sujeitos que confirmaram a norma jurídica, porque isto constituiria uma perversão do discurso normativo. Neste caso, esta homologia acarretaria uma imposição unilateral, onde só um teria competência para falar, sendo que os outros deveriam apenas obedecer, pelo sim ou pelo não. Trata-se de uma hipótese limite, pois a possibilidade do sujeito reagir seletivamente desaparece. Confirmando ou não a mensagem, ele será punido. $\mathrm{O}$ emissor age pelo receptor e o aniquila.

Neste sentido, a relação complementar desaparece, pois não há mais o jogo de ação e reação. Existe somente a coação que destrói a relação de poder. É evidente que esta análise pragmática do problema da justiça, que também leva em conta a sua dimensão semântica, caracteriza uma situação limite que destrói a relação complementar, por fazer justamente o inverso do que deveria fazer, através do exercício da violência simbólica: expor as relações de força que estão na base da relação desigual que estabelece. Isto demonstra o fato de que os cometimentos normativos institucionalizados, no limite, não podem suportar estes relatos que produzem defeitos na relação. A seguir, veremos a presença desta temática na tragédia shakespeariana.

4. A generalização das reações desconfirmadoras em Coriolano e o problema das comunicações normativas abusivas

Na visão de Bárbara Heliodora, Coriolano é uma peça moderna e ousada para o seu tempo, com a presença nítida de uma visão interativa de poder. Mostra que, às vezes, para se manter a harmonia, o grupo social tem de optar pela defesa dos direitos dos mais necessitados, combatendo os abusos e erros daqueles cujos privilégios já são grandes. Como uma espécie de tragédia de exposição da violência simbólica e não de sua afirmação, Shakespeare não se restringe ao fato histórico estrito e desenvolve uma releitura dramática e crítica a respeito das qualidades e defeitos que fazem ou desfazem o homem público ou o governante. $\mathrm{O}$ bardo faz um julgamento estético por meio do teatro e do drama, sem que este julgamento seja simplista ao reforçar ideias absolutas em torno do certo e errado. ${ }^{55}$

Ao analisar Roma, já vivia em Londres há dezesseis anos, seu pensamento já estava mais amadurecido, ele estuda, avalia e examina a vida dos poderosos e dos humildes, em termos interativos, daí a possibilidade de associação com a teoria pragmática do poder. $\mathrm{O}$ ato político pode ser analisado com objetividade, mais liberdade e menos censura, já que não escrevia sobre a vida política inglesa em nem sobre o cristianismo. Em Coriolano, Shakespeare mostra uma situação de conflito de classes para examinar a

55 HELIODORA, Bárbara. Falando de Shakespeare. São Paulo: Perspectiva, 2001. p. 156. 
fundo a relação entre as virtudes públicas e privadas, a influência da personalidade, do temperamento do indivíduo sobre as suas possibilidades de participação interativa na vida pública, ao mesmo tempo em que mostra como a massa popular é volúvel e vulnerável ao discurso persuasivo de violência simbólica. ${ }^{56}$

Ele não é visto como um herói idealizado que foi vítima de conspirações, ele é retratado dentro da dialógica homo sapiens/demens, exposta por Morin. Coriolano é uma figura desmesurada e desagradável, com um temperamento explosivo, produto de uma educação desequilibrada, que o torna incapaz de diferenciar violência e poder e de obedecer às regras do contrato social em termos interativos. Ele é um herói de guerra, seu corpo é uma máquina de violência física eficiente, mas ele é incapaz de assumir, pessoalmente, a ideia de poder interativo como violência simbólica ligado a comunicação normativa. Testemunhamos, segundo a autora, o lamentável desperdício de um grande potencial humano. ${ }^{57}$ Esta obra não idealiza nem demoniza o seu protagonista, vemos nela uma maravilhosa ambivalência de uma obra de arte que nos permite ampliar nosso conhecimento a respeito de comportamentos humanos por meio da experiência estética. Ele nos enriquece, no plano intelectual, em todos os aspectos do comportamento humano, na sua ambígua complexidade. O bardo amou e respeitou o ser humano sem precisar construir modelos ideais, tão presentes no mundo teórico contemporâneo.

Logo no início da peça, o cenário indica a presença de uma crise de legitimidade na república romana, onde as relações de poder e de força estão expostas e as relações metacomplementares dos patrícios enfraquecidas, tendo em vista a presença de reações desconfirmadoras generalizadas. Os patrícios pertenciam a nobreza familiar e gozavam de privilégios, como a isenção de tributos e possibilidade de pertencer ao senado. A plebe, apesar de pertencer a categoria com menos privilégio político e econômico, superou a opressão do período monárquico e adquiriu o poder de eleger tribunos que tinham poder de veto sobre leis vindas do senado. A eleição dos cônsules visava coibir atos abusivos políticos dos patrícios.

A primeira cena do primeiro ato mostra a desconfirmação pragmática da autoridade do governo romano por um grupo de cidadãos, armados, diante da fome. A autoridade, a liderança e a reputação de Caio Márcio são atacadas. O dissenso social, exposto na desigualdade e no injusto orgulho do general é alvo de conflito, expondo as relações de força que estão na base da comunicação normativa, que numa situação normal deveriam ser dissimuladas. Eles afirmam a intenção de promover uma desconfirmação violenta, estão dispostos a morrer pela sua causa e veem Caio Márcio como seu principal inimigo, que tem a sua autoridade metacomplementar desgastada. O general é considerado 
responsável pela alta dos preços do trigo, mesmo quando está armazenado em abundância. Percebe-se a presença de uma "conflituosa discussão contra" entre patrícios e plebeus, onde estes discutem a legitimidade das leis abusivas que favorecem apenas aos ricos, e geram a fome entre os plebeus, chegando ao ponto de decidir pela morte do protagonista. ${ }^{58}$

$1^{\circ}$ CIDADÃO

Estão todos aqui resolvidos a morrer, antes que passar fome?

\section{TODOS}

Estamos resolvidos. Resolvidos.

\section{$2^{\circ}$ CIDADÃO}

Para começar, sabem que Caio Márcio é o principal inimigo?

\section{TODOS}

Sabemos, sabemos.

\section{$2{ }^{\circ}$ CIDADÃO}

Vamos mata-lo, pois teremos o trigo ao nosso preço. É esse o veredicto?

\section{TODOS}

Chega de falar. É fazer e pronto. Vamos! Vamos!

\section{$1{ }^{\circ}$ CIDADÃO}

Somos tidos como maus cidadãos, os patrícios como bons. Se eles nos cedessem apenas o que para eles é sobra, enquanto está saudável, poderíamos julgar que nos aliviaram por humanidade. Mas nós valemos muito para eles. A magreza que nos aflige, a nossa miséria concreta, são uma espécie de inventário que dá conta detalhada de sua abundância. $O$ nosso sofrimento é ganho para eles. Vinguemo-nos de tudo isso com nossas pás antes que eles nos transformem em dentes de ancinhos. Pois os Deuses sabem que digo isso por fome de pão, não por sede de vingança.

\section{$2^{\circ}$ CIDADÃO}

Pretende agir especialmente contra Caio Márcio? Levaram em conta os serviços que ele prestou ao pais?

\section{$1^{\circ} \mathrm{CIDADÃO}$}

Tudo que ele fez de bom foi só para este fim. Embora os que não pensam, possam dizer que tudo foi pela pátria ele fez tudo para dar satisfação à mãe, em parte, por seu orgulho, que ainda é maior do que suas virtudes.

58 SHAKESPEARE, William. Coriolano. In: SHAKESPEARE, William. Teatro completo: tragédias e comédias sombrias. Tradução Bárbara Heliodora. Rio de Janeiro: Nova Aguilar, 2006. v. 1, p. 1.119-1.120. 
Menênio Agripa, um cônsul romano com autoridade institucionalizada pelo povo, aparece em cena e arma um discurso persuasivo e metafórico para neutralizar a desconfirmação das massas e fortalecer, em termos comunicativos, a autoridade, a liderança e a reputação dos patrícios. Ele é o contraponto da figura de Caio Márcio, ele é amável na sua fala, referindo-se aos plebeus como mestres, amigos e vizinhos, neutralizando o dissenso social presente e reforçando a ideia de poder como liderança. Na tentativa de conter a revolta, reafirma a ideia de poder como reputação, vale-se da metáfora das partes do corpo, onde o senado seria a barriga e povo o dedão do pé. Como a barriga recebe os alimentos que mantém vivo todo o corpo, ao distribuí-lo pelo organismo, seria injusto revoltar-se contra ela, acusando-a de não trabalhar. Da mesma forma, percebe-se que o benefício público para o povo advém do senado. ${ }^{59}$

\section{MENÊNIO}

Ouça bem amigo.

Ao contrário do afã dos atacantes,

A barriga responde após pensar:

"É bem verdade, amigos tão unidos,

Que eu recebo de início os alimentos

Que os mantém vivos, o que é justo e é certo,

Pois sou do corpo o armazém e a loja;

E os manda, pelos rios de seu sangue,

A corte-coração, ao trono-cérebro.

Todos os cantos e tendões do homem,

Do maior nervo à mais humilde veia,

De mim recebem a ração normal

Com a qual vivem. Se não podem todos"

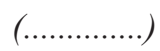

Os senadores são esta barriga,

Vocês os revoltosos. Se examinam

Os cuidados que têm e compreendem

Tudo o que toca o bem comum, verão

Que não recebem benefício público

59 SHAKESPEARE, William. Coriolano. In: SHAKESPEARE, William. Teatro completo: tragédias e comédias sombrias. Tradução Bárbara Heliodora. Rio de Janeiro: Nova Aguilar, 2006. v. 1, p. 1.122-1.123. 
Que não proceda deles para vocês,

E não de vocês mesmos. Que me diz

Você, dedão do pé desta assembleia?

Caio Márcio entra em cena e expõe, com muita clareza, a sua visão aristocrática e não interativa do poder. Afirma a sua superioridade natural como forma de desconfirmação da desconfirmação, neste caso feita de forma atípica, pois desconfirma também a tradição normativa dominante e não apenas a desconfirmação dos plebeus. Constrói um discurso violento em termos reais e não simbólicos, ao contrário de Menênio, expõe as relações de força desiguais que estão na base na relação entre patrícios e plebeus. Mostra o seu desprezo pelo povo e sua inconstância, afirmando a existência de uma desigualdade natural na sociedade.

Também manifesta profundo pesar pela eleição dos tribunos da plebe, o que mostra indícios de uma forma de comunicação abusiva, nos termos pragmáticos, que também desconfirma os padrões normativos dominantes. Ele aniquila a plebe e seus tribunos como sujeitos, usando um discurso violento. Se os plebeus são tidos naturalmente como inferiores, mesmo que confirmem a ordem legal, devem ser sancionados. O discurso de Caio Márcio para a plebe rompe a complementaridade, destruindo a relação de poder e tornando-se coativo e injusto. Como afirma Bárbara Heliodora,

a agressão nasce de um preconceito geral, já que ele, naturalmente, pertencia à aristocracia. $\mathrm{O}$ conceito de que todo governo repousa, em última análise, no consentimento dos governados, apenas nascia naquele momento, mas sua importância crescia inexoravelmente até marcar a independência americana e a revolução francesa. Ele ofendia e espezinhava aqueles de quem se considerava governante nato. Todavia, é ele quem desrespeita leis do Estado romano, insistindo que o povo não deve ser ouvido, pois fazê-lo seria sinal de fraqueza da classe dominante. ${ }^{60}$

A violência física, e não a simbólica, aparece de forma explícita da agressividade do tom da sua voz e na rudeza de suas palavras quando afirma, ao expor o homo demens: ${ }^{61}$

CAIO MÁRCIO

O que há ralé briguenta?

Quem for gentil com vocês só bajula

${ }_{60}$ HELIODORA, Bárbara. Falando de Shakespeare. São Paulo: Perspectiva, 2001. p. 163.

${ }_{61}$ SHAKESPEARE, William. Coriolano. In: SHAKESPEARE, William. Teatro completo: tragédias e comédias sombrias. Tradução Bárbara Heliodora. Rio de Janeiro: Nova Aguilar, 2006. v. 1, p. 1.125 e 1.126. 
O que querem cachorros?

Confiar em quem muda a toda hora?

Vão embora para casa seus frangalhos.

(...............)

Que morram! Choram fome, citem motes

Que a fome fura muros, que os cães comem,

Que carne é pras suas bocas, e que os deuses

Não dão trigo só pros ricos. Tais trapos

Abanam suas queixas que, atendidas,

Pois é golpe mortal contra a nobreza

E deixa exangue o poder-jogam longe

Os gorros, como se para os pendurar

Lá nos cornos da lua, e cada um

Gritando mais do que outro.

Cinco tribunos eleitos por eles

Para defender sua sabedoria.

Julio Brutus é um, outro é Veluto

Sei lá! Malditos! Ficaria a Roma

Arrasada e sem tetos antes que eu

O aprovasse. Com o passar do tempo

Esse poder aumenta e ainda provoca

Mais brigas e levantes.

Em seguida, Caio Márcio é informado sobre uma nova desconfirmação violenta por parte dos Vólcios em Corioli, a crise de legitimidade da autoridade romana é muito ampla, saindo dos domínios de Roma. Ele mostra-se pronto para a guerra, e vê a violência física como forma exclusiva de reafirmação de sua honra e da autoridade romana. Na terceira cena, a mãe de Caio Márcio, Volúmnia, conversa com e esposa dele, Virgília, e elogia o talento bélico do filho destacando que mesmo a morte seria uma honra e a firmação de sua reputação e liderança. Fica clara a influência de sua educação unilateral em fazer dele uma implacável máquina de guerra. A quarta cena representa a guerra em Corioli. Caio Márcio fica preso sozinho dentro dos portões da cidade, mostra o seu caráter bélico e a sua coragem, sua extraordinária violência física. Ele está sozinho para enfrentar a cidade inteira. Na oitava cena, confirma-se o confronto violento entre Caio Márcio e Aufídio, que é derrotado, reafirmando a autoridade do governo romano. Ele volta a Roma, coberto de sangue, e é aclamado com o cognome de Coriolano, como uma espécie de confirmação de seu heroísmo bélico. Neste ponto, a autoridade de Coriolano 
é confirmada, há um projeto de fortalecer a sua institucionalização tornando-o cônsul. O tribuno da plebe Comínio afirma: "Caio Márcio Coriolano usa com honra tal cognome!”62

A primeira cena do segundo ato mostra a "discussão contra" entre Menênio e dois tribunos da plebe, que consideram ser Coriolano arrogante e orgulhoso. Menênio diz que eles não conhecem a si próprios e aponta uma série de defeitos nestes, na tentativa de reafirmar a autoridade e a liderança de Coriolano..$^{63}$ Em diálogo posterior, os tribunos da plebe Comínio e Brutus entendem que Coriolano pode tornar-se Cônsul e ameaçar o seu poder no senado. Afirmam: "Nossa autoridade com ele no poder irá dormir". Brutus jura que ouviu a ele dizer que jamais vai se rebaixar para implorar o voto do povo, como manda o costume. Assim conspiram: ${ }^{64}$

\section{BRUTUS}

Senão se acaba a nossa autoridade;

Nós temos de lembrar ao povo o ódio

Em que ele sempre o teve e que, mandando,

Vai usá-los para mulas, vai calá-los

Tolher suas liberdades para julgá-los

\section{SICÍNIO}

Em hora que a sua pose e insolência

Toquem no povo - o que não vai faltar,

Sendo ele provocado, o que é mais fácil

Que atiçar cães - então o fogo dele

Acende a palha seca, e a chama dele

O apaga para sempre.

Na segunda cena, em contraposição à visão negativa dos tribunos da plebe, exibe-se o diálogo entre dois Oficiais, discutindo a candidatura de Coriolano ao consulado. Ambos fazem uma análise não maniqueísta de seu caráter, destacando um lado positivo de Coriolano que seria a sua sinceridade, de assumir o seu ódio ao povo que confirma os bajuladores. Percebemos aqui a intenção de Shakespeare em afirmar a complexidade do personagem, já que o povo também não se mostra completamente esclarecido em termos

62 SHAKESPEARE, William. Coriolano. In: SHAKESPEARE, William. Teatro completo: tragédias e comédias sombrias. Tradução Bárbara Heliodora. Rio de Janeiro: Nova Aguilar, 2006. v. 1, p. 1.149.

63 SHAKESPEARE, William. op. cit., p. 1.155.

${ }^{64}$ SHAKESPEARE, William. op. cit., p. 1.161. 
do poder de violência simbólica da linguagem, na medida em que o confirma, em certa medida. Afirma um deles: ${ }^{65}$

\section{$2^{\circ}$ OFICIAL}

A verdade é que tem havido muitos grandes homens que bajulam o povo sem jamais amálo; e muitos que este amou sem saber por que; de modo que se o povo ama sem saber por que, ele também odeia sem melhor razão. Assim sendo, Coriolano pouco importa se é amado ou odiado por ele, isto expressa seu verdadeiro conhecimento da disposição da gentalha, e com nobre desdém permite que todos o percebem.

A seguir, o Senado comunica a Coriolano que pretende que ele se torne cônsul, mas Menênio, preocupado com o problema da legitimidade, diz que ele deve seguir a tradição jurídico-política e pedir votos ao povo, que deve confirma-lo como autoridade meta-complementar. Coriolano, que tem uma visão não interativa do poder, sentindo-se naturalmente nobre e superior a plebe, pede ao Senado para não valer este costume. Percebemos a sua dificuldade em comunicar-se na condição de sujeito (aspecto cometimento de inferioridade) e confirmar a autoridade do povo para que ele próprio o confirme como autoridade. Ele deve comunicar o cometimento na condição de sujeito da relação e cumprir o costume. ${ }^{66}$

Na terceira cena, uma interação comunicativa é constituída, pois os cidadãos comentam que, se Coriolano, na condição de sujeito da relação, pedir os votos e mostrar as suas feridas, eles devem aceitar a sua autoridade e dar os seus votos, confirmando-o como cônsul. ${ }^{67}$ Coriolano entra com a veste da humildade, como uma forma de comunicação não verbal da condição de sujeito, reconhecendo e confirmando o poder do povo. Na condição de autoridade, eles determinam que ele deva fazer o pedido individualmente. No início, ele permanece arrogante, não alcançando a condição de sujeito. Mas Menênio destaca que ele deve falar de modo mais amável, ou seja, de forma em que o seu desprezo seja dissimulado na forma de um exercício de violência simbólica que reforce a ideia de poder como liderança e reputação para uma final confirmação do poder como autoridade. A seguir, um dos cidadãos diz que ele deve pedir com bondade e ele o faz com uma discreta relutância, mas acaba por não mostrar as cicatrizes dos ferimentos. Em particular, ele confessa o seu pesar por ter de confirmar a tradição da confirmação popular: ${ }^{68}$

\footnotetext{
65 SHAKESPEARE, William. op. cit., p. 1.164.

66 SHAKESPEARE, William. op. cit., p. 1.169.

67 SHAKESPEARE, William. op. cit., p. 1.170.

68 SHAKESPEARE, William. op. cit., p. 1.173.
} 


\section{CIDADÃO}

Temos em nós o poder de fazê-lo, mas é um poder que não temos poder para executar. Pois se ele nos mostrar seus ferimentos e nos contar seus feitos, temos de condicionar nossas línguas por estas feridas e votar nelas. De modo que se ele nos contar seus nobres feitos, teremos também de contar a ele que nobremente nós o aceitamos. A ingratidão é monstruosa e multidão ser ingrata é fazer dela um monstro; e da qual sendo nós membros, isso nos levaria a ser membros monstruosos.

\section{CORIOLANO}

Em mim? Que morram!

Só quero que me esqueçam, como esquecem

Das virtudes que os sábios neles gastam

\section{MENÊNIO}

Estraga tudo. Já vou. Fale com eles de modo mais saudável.

\section{CORIOLANO}

Bondosamente, senhor, rogo que me deem. Tenho ferimentos para mostrar-lhes, que os satisfarão em particular. Seu bom voto, senhor, o que me diz?

\section{CIDADÃO}

Que o terá, meu honrado senhor.

\section{CORIOLANO}

Por favor, se for possivel ao tom de suas vozes concordar que eu seja cônsul, estou aqui com o traje habitual.

Depois que os cidadãos saem ele revela o seu sentimento de pesar pela afirmação do costume:

\section{CORIOLANO}

Que votos doces!

Antes morrer, morrer até de fome,

Que mendigar o preço que eu mereço

Por que com toga de lobo eu ficar Até um João Ninguém aqui me dar

Seu voto indispensável? É a tradição.

E como ela quer as coisas são.

Ele conquista os votos do povo, faltam os do senado, sua autoridade de cônsul foi confirmada pela plebe. No entanto, a instabilidade pragmática está longe de 
terminar. Os tribunos da plebe, Brutus e Sicínio, controlam a seletividade da ação dos cidadãos contra a autoridade de Coriolano recém-confirmada, reforçando a desconfiança deles em relação a Coriolano, alegando que o fato de não ter mostrado as cicatrizes demonstra que o seu discurso humilde era dissimulado e que ele vai tirar a liberdade deles. Alguns pensam que ele fez o pedido com deboche. Os tribunos persuadem os cidadãos a desconfirmar a eleição e a confirmação do seu voto e planejam usar o gênio explosivo de Coriolano contra ele próprio. ${ }^{69}$

\section{SICÍNIO}

Então, mestres, escolheram este homem?

\section{CIDADÃO}

Senhor, ele tem os nossos votos.

\section{BRUTUS}

Praza aos deuses mereça o seu amor.

\section{CIDADÃO}

Amém; mas pro meu pobre entendimento

Zombou de nós pedindo o voto.

\section{SICÍNIO}

Mas por que foram tolos para vê-lo,

Ou mesmo vendo, quais crianças tolas,

Deram seus votos?

\section{BRUTUS}

Por que não falaram

Segundo o que aprenderam? Sem poder,

Quando era mero servidor do Estado,

Sempre foi inimigo, e falou contra

As leis e liberdades que hoje têm

Nesta comunidade; e se ora chega

A lugar de poder e de governo,

Se continua com malignidade

Inimigo do povo, deram seus votos

Pra própria maldição?

$\overline{69}$ SHAKESPEARE, William. op. cit., p. 1.180. 


\section{CIDADÃO}

Não confirmamos; podemos negar

\section{CIDADÃO}

E vamos recusá-lo!

Só eu tenho quinhentos votos contra

BRUTUS

Pois vão dizer a seus amigos

Que o cônsul que elegeram vai tirar-lhes

As liberdades, dar-lhes tanta voz

Quanto o cão que é surrado por latir

E por calar.

Depois que o povo sai, Brutus assume a atitude desconfirmadora da eleição planejada:

\section{BRUTUS}

É melhor arriscar esse motim

Do que esperar momento mais seguro.

Se ele se enfurecer, como é normal,

Com essa recusa, havemos de tirar

Vantagem desta fúria.

$\mathrm{Na}$ primeira cena do terceiro ato, Coriolano está com os senadores, a aristocracia e os tribunos da plebe. No início, ele ainda pensa na guerra, em Aufídio, pois recebe a notícia de que este o odeia e sonha em vencê-lo. Mais uma vez, ele mostra desprezo em relação aos tribunos da plebe e sua autoridade, e não consegue dissimular o seu discurso desconfirmador em potencial, que foi reprimido no pedido de votos ao povo. Como estratégia discursiva, Brutus e Sicínio dizem que não foi eleito e que o povo estaria irado contra ele. Alega que ele está queixoso do seu deboche. Ele é advertido a não ir ao mercado, pois o povo estaria irado está apto a desconfirmá-lo como cônsul.

Coriolano, muito irritado, destitui o mínimo de violência simbólica por ele mesmo construída, propaga o seu discurso desconfirmador da participação política do povo na confirmação da sua autoridade como cônsul: ${ }^{70}$

$\overline{70}$ SHAKESPEARE, William. op. cit., p. 1.183. 


\section{CORIOLANO}

Mas o que é isso?

\section{SICÍNIO}

É perigoso seguir. Pare aí.

\section{CORIOLANO}

Mas que mudança é esta?

\section{COMÍNIO}

Não foi eleito por comuns e nobres?

\section{BRUTUS}

Não, Comínio.

\section{CORIOLANO}

Votaram só crianças?

Isto é conluio e tem como propósito

Cercear a vontade da nobreza:

Aceitá-lo é viver com o que não sabe

Nem governar e ser governado.

\section{SICÍNIO}

E agora mostra

Tudo o que irrita o povo. Se passar

Para onde quer ir, há que indagar

O caminho perdido com bons modos

Ou nem terá a nobreza de cônsul

Nem jugo de tribuno.

\section{CORIOLANO}

Agora, sim. Aos meus nobres amigos

Eu imploro perdão

E a multidão, mutável, fedorenta,

Se olharem pra mim, que os não bajulo,

Hão de ver como são. E aqui repito:

Se os agradarmos, só alimentamos

Contra o Senado um joio de rebeldes

Sedição, insolência, que nós mesmos

Plantamos e espalhamos ao mesclarmos

Conosco quem não tem virtude ou força

Senão as que ganharam por esmola. 
Menênio pede que ele se cale, mas ele continua a discussão-contra de forma inflamada e desconfirmadora: ${ }^{71}$

\section{CORIOLANO}

Mesmo o povo tendo mais poder lá

Nutriu apenas a desobediência

E a ruína do Estado.

A seguir, ele desconfirma a autoridade dos próprios tribunos da plebe, pois, de forma abusiva, é acusado de traição por eles: ${ }^{72}$

\section{SICÍNIO}

Falou como traidor, e, qual traidor,

Ele há de responder.

\section{CORIOLANO}

Tolo infeliz!

Por que há de ter o povo tais tribunos?

Com o apoio deles, vai-se a obediência

Ao poder superior. Numa revolta,

Não por ser certo, mas por necessário,

Foram eleitos. Em melhor momento,

Seja certo dizermos o que é certo,

Ejogar na poeira tais poderes.

BRUTUS

Isso é traição!

\section{SICÍNIO}

Esse aí, cônsul? Nunca!

Na tentativa de reafirmação da autoridade romana, é ordenada a prisão de Coriolano, como forma de transformação da desconfirmação em rejeição ilícita. O povo é chamado a participar. Sicínio diz ao povo que Coriolano quer retirar o seu poder, ao desconfirmá-lo, num momento de reafirmação da autoridade dos tribunos da plebe e do poder do povo. Brutus pede a morte de Coriolano, exigindo que ele se entregue na condição de sujeito criminoso. ${ }^{73}$

\footnotetext{
$71 \quad$ SHAKESPEARE, William. op. cit., p. 1.187.

72 SHAKESPEARE, William. op. cit., p. 1.188.

73 SHAKESPEARE, William. op. cit., p. 1.192. 


\section{SICÍNIO}

Estão para perder suas liberdades:

Márcio lhes tiraria tudo, Márcio

A quem odeiam, elegeram cônsul.

O que é a cidade, se não o povo?

\section{TODOS OS PLEBEUS}

Verdade, o povo é que faz a cidade.

\section{BRUTUS}

Por consenso geral nós fomos feitos

Magistrados do povo.

Ou afinamos a nossa autoridade

Ou a perdemos aqui: aqui proclamamos

Por esse povo, por cujo poder

Fomos eleitos, que Márcio merece

Morte imediata.

\section{SICÍNIO}

Há de ser atirado na Tarpeía

Por duras mãos: ele foi contra a lei,

Portanto a lei lhe nega julgamento

Fora da força severa do povo,

Que para ele é nada.

Coriolano não cede e puxa a sua espada num ato ainda mais desconfirmador e violento. O povo é controlado, todos os senadores pedem que Coriolano vá para casa e ele vai. Menênio conversa com os tribunos da plebe e com o povo e mais uma vez tenta obter a confirmação de Coriolano como cônsul, tentando persuadi-lo a respeito de suas boas qualidades. Em contrapartida, Sicínio aponta o abuso de poder, em termos pragmáticos, praticado por Coriolano: ${ }^{74}$

$\mathrm{Na}$ segunda cena, Volúmnia, mãe de Coriolano, tenta controlar a sua seletividade no sentido de construir uma violência simbólica, dissimulando o seu temperamento violento e sua inclinação a se comunicar de forma abusiva com os plebeus. Ele foi criado para ser um sincero e arrogante herói de guerra, mas a mãe exige que ele aprenda a linguagem persuasiva e dissimulada do poder. Nas palavras de Bárbara Heliodora, ela parece ter consciência de que a sua educação o tornou incapaz de encarar a

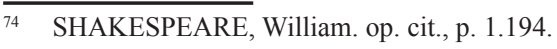


vida em termos que não os do campo de batalha (falha fundamental como cidadão e como candidato a governante). ${ }^{75}$ Agora, ela parece estar insatisfeita com seu lado violento e irracional (homo demens) e cobra o emergir de uma racionalidade política (homo sapiens) para qual ele não se sente preparado. ${ }^{76}$

\section{CORIOLANO}

Espanta-me que minha mãe

Não me aplauda mais, já que sempre os disse

Uns escravos lanudos, inventados,

Para serem negociados por tostões,

Sem chapéu, boquiabertos, deslumbrados

\section{VOLÚMNIA}

Devia vestir bem o seu poder,

Antes de esfarrapá-lo.

Bem poderia ser o homem que é,

Tentando menos: seriam menores

Os seus tropeços de temperamento

Se não mostrasse tudo o que sentia

Antes que não pudessem mais frustrá-lo.

$(\ldots \ldots \ldots \ldots)$

É bom que ouça

Meu coração é rijo como o seu

Porém meu cérebro utiliza a raiva

Com mais proveito.

(............)

Por que agora é que lhe vai caber

Falar ao povo não pelo que pensa

Nem pelo que diz o coração,

Mas com palavras decoradas.

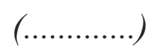

Eu lhe imploro meu filho,

Vá com eles, de chapéu na mão,

75 HELIODORA, Bárbara. Falando de Shakespeare. São Paulo: Perspectiva, 2001. p. 1.198.

76 SHAKESPEARE, William. op. cit., p. 1.198. 
E se já chegou a tanto - siga os outros

Beije o chão com o joelho, e os olhos do ignorante

Valem mais que os ouvidos; com a cabeça.

Percebemos que a mãe tem o poder de controlar a seletividade de Coriolano, que é persuadido, por ela, a usar a língua falsa (homo sapiens) e trair o seu coração (homo demens). Menênio diz que ele deve "falar doce", voltar e pedir desculpas aos tribunos, expondo um aspecto cometimento comunicativo de inferioridade, e depois, de igualdade. ${ }^{77}$

\section{CORIOLANO}

Calma, eu lhe peço.

Mãe, não me repreenda; eu já vou indo

Para o mercado. Qual um saltimbanco

Conquisto os corações e volto amado

Por todos os ofícios, Saúdo minha esposa. Volto cônsul,

Ou nunca mais confiem nesta língua

Para mais bajulações.

$\mathrm{Na}$ terceira cena, ocorre o confronto decisivo entre Sicínio, Brutus, Menênio, Coriolano e os Senadores. Os tribunos pretendem reunir o povo, em nome do direito dos comuns, a fim de boicotar a confirmação da eleição de cônsul, transformando a desconfirmação de Coriolano, já anunciada, previamente, em rejeição ilícita, impondo pena de morte, multa ou banimento. Combinam de instigar a ira de Coriolano, como forma de confronto do forte poder de manipulação da palavra em face do fraco poder da força física, como elemento da afirmação da autoridade política.

Visualizamos uma disputa em torno do aspecto-cometimento da relação: quem deve falar primeiro? Coriolano ou os tribunos? Sicínio exige que ele se submeta aos pressupostos do voto popular e a censura legal por qualquer falta. Coriolano confirma a norma da tradição. Menênio usa argumentos persuasivos em torno de seu heroísmo guerreiro: haveria, nele, sempre um soldado, ele é rude, mas não malévolo. Coriolano menciona na incoerência popular de pretender desconfirmar aquilo que previamente foi confirmado.

\section{SICÍNIO}

Eu exijo

Que submetido ao voto popular,

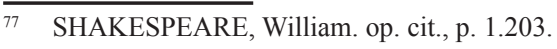


Respeite os seus prepostos resignando-se

À censura legal por qualquer falta

Que se prove contra si.

\section{CORIOLANO}

Eu concordo

\section{MENÊNIO}

Que se fala não como um cidadão,

Nele há sempre o soldado. Não confundam

Seus tons mais rudes com algo malévolo;

São, como disse, dignos de um soldado.

E não ofensa ao povo.

\section{CORIOLANO}

Por que razão,

Sendo eleito cônsul com seus votos

Fico tão desonrado que em uma hora

Retiram o já dado?

A seguir, como estratégia discursiva, Sicínio intenta fazer brotar a violência física de Coriolano, naquele breve momento transformada em simbólica: o acusa de conspiração para se tornar um poder tirânico, e de ser um traidor do povo. Ao ouvir a palavra "traidor" ele se rebela por também sentir-se alvo de uma comunicação abusiva, sem perceber, que está sendo manipulado pelos tribunos, e expõe as relações de força dissimuladas e desconfirma, mais uma vez, os tribunos e o povo. Aqui temos uma relação de poder constituída pelos tribunos, que leva a destruição da relação de poder de Coriolano em relação ao povo. ${ }^{78}$

\section{SICÍNIO}

Nós o acusamos de ter conspirado

Para se fixar como poder tirânico;

O que o transforma em traidor do povo.

\section{CORIOLANO}

O que? traidor?

$\overline{78}$ SHAKESPEARE, William. op. cit., p. 1.207. 


\section{MENÊNIO}

\section{Com calma! Prometeu!}

\section{CORIOLANO}

Que o pior dos infernos queime o povo!

Eu sou traidor? Tribuno Injurioso!

Nem com vinte mil mortes neste olhar,

Milhões em tuas mãos e a soma

Na tua falsa língua, e eu insistiria

Em dizer-te "tu mentes com a clareza

Com que aos Deuses rezo.

\section{TODOS OS PLEBEUS}

Pra rocha! Pra rocha com ele!

Percebemos que também o povo na condição de autoridade é levado pelos tribunos a assumir uma espécie de comunicação normativa abusiva em relação a Coriolano. Mesmo após evitar a conhecida atitude abusiva em relação a eles e confirmar o costume, uma segunda vez, ele é considerado um traidor criminoso. A seletividade da ação do povo é controlada pelos tribunos, pois ele é levado a crer, pelo seu comportamento passado, que Coriolano exerceria uma comunicação abusiva, futura, na função de cônsul, que de fato acaba por se firmar neste momento. Sicínio, a seguir, usa, mais uma vez, a estratégia linguística de transformar a desconfirmação em uma rejeição ilícita ao afirmar:

\section{SICÍNIO}

Não preciso de mais acusações

Tudo o que viram fazer ou dizer

Batendo em uns e maldizendo os outros,

Com agressões à lei, desafiando

Aqueles com poder para julgá-lo

É criminoso em nível capital,

Merece a pior morte.

Sicínio comunica a sentença de banimento da cidade, sob pena de arremesso do alto da Tarpéia. A revolta de Coriolano é cada vez mais afirmada, e, desta vez, bastante radical. Ele promove um tipo de axiomatização do discurso dogmático de sua autoridade que o torna irracional, ao suprimir a seu caráter dialógico. Shakespeare, conscientemente, deixa sem explicação a agressividade para com os Tribunos ou o povo e sem justificativa os insultos e as acusações que se sucedem na sua fala agressiva. Segundo Bárbara Heliodora, na violência da linguagem do protagonista, vemos que o seu comportamento o 
conduziu ao fim que teve, nele encontramos o tipo de deformação, de insensibilidade aos valores não-guerreiros da vida. Por outro lado, a massa tem uma natureza infantil e pode ser conduzida com facilidade. Ele é o leão, mas não sabe ser raposa, como seus pares. ${ }^{79}$ Mais uma vez, ele desconfirma a sua condição de criminoso e toda autoridade de Roma, tanto dos patrícios e plebeus: ${ }^{80}$

\section{CORIOLANO}

Ó matilha de cães de hálito imundo

Como o do poço envenenado! Odeio-os

Como às carcaças que, desenterradas, corrompe-nos o ar. Eu os renego;

Fiquem aqui com suas incertezas

Que até boatos fazem palpitar!

Que o farfalhar das plumas do inimigo

Enchem de horror! Terão poder ainda

Para banir os fiéis - até que um dia

Sua ignorância (que não pensa, sente)

Que só poupou vocês, vai entrega-los

Como o mais humilhado dos cativos

A uma nação que os vença sem um golpe

Por você eu desprezo Roma e parto:

Existe um mundo fora destes muros!

\section{PLEBEUS}

Nosso inimigo foi banido! Ele partiu! Se foi!

Na primeira cena do quarto ato, Coriolano despede-se da mãe e esposa, de Menênio e Comínio. Volúmnia afronta Sicínio, dizendo que ele foi uma raposa em alusão a Maquiavel, que baniu quem mais lutou por Roma, apenas proferindo discursos. $\mathrm{Na}$ quarta cena, Coriolano chega a uma nova cidade, Corioli, com trajes pobres, disfarçado. É bem recebido por Aufídio e se torna seu aliado, confirmando a sua autoridade. Neste momento, percebemos como a sua transformação em inimigo de Roma, desconfirma a sua pena de banimento pela prática de ato ilícito. ${ }^{81}$

$\mathrm{Na}$ sexta cena, os tribunos pensam que são vitoriosos, mas recebem a notícia de que Coriolano se aliou a Aufídio para invadir Roma. Ocorre uma clara inversão de posições de poder. Coriolano passa a dominar novamente, mas em termos informais,

\footnotetext{
79 HELIODORA, Bárbara. Falando de Shakespeare. São Paulo: Perspectiva, 2001. p. 168.

80 SHAKESPEARE, William. op. cit., p. 1.209-1.210.

${ }^{81}$ SHAKESPEARE, William. op. cit., p. 1.228.
} 
através da díade forte/fraco, relacionado ao código da violência. Ele se institucionaliza como autoridade dos Vólcios, em termos de liderança e reputação. Menênio diz que todos estão perdidos, a não ser que Coriolano tenha piedade. O povo se arrepende de tê-lo banido, pois, sabe que em um confronto de guerra não há como vencê-lo. ${ }^{82} \mathrm{~A}$ ameaça de violência passa a constituir uma nova relação de poder com os romanos. Na sétima cena o diálogo entre Aufídio e seu tenente ressaltam a institucionalização da autoridade de Coriolano. $^{83}$

A primeira cena do quinto ato mostra que Comínio não teve sucesso ao falar com Coriolano. Todos decidem que Menênio deve tentar falar com ele e implorar por seu perdão. Refere-se a ele como sendo "seu filho", mas Coriolano diz que não conhece esposa, mãe ou filho, agora ele serve outros e quer vingança, mas depois confessa que devolveu Menênio com o coração partido. ${ }^{84}$

A seguir, entram Volúmnia e Virgília. Volúmnia, de forma estratégica, ajoelha-se diante de Coriolano, expondo uma comunicação com cometimento complementar não verbal de submissão, que inverte a relação de autoridade materna. Ela propõe que seja feito um acordo de paz com um homem que foi domesticado para a guerra, numa espécie de ato desconfirmador da sua personalidade guerreira. Ele pede para que ela não suplique perdão para os romanos. Volúmnia pede para ser ouvida e invoca argumentos emocionais e familiares, usando claramente recursos de violência simbólica na sua fala, em termos de reputação. ${ }^{85}$

\section{VOLÚMNIA}

Não nos deixe.

Fosse acaso intenção de vossa súplica

Para salvas os romanos destruir

Os Vólcios a que serves, poderias

Dizer que envenenamos a sua honra;

Mas só pedimos que se reconcilies

Poderão Vólcios dizer "Perdoamos"

E ambos, ao louvar-te, gritariam

"Abençoado o que nos trouxe a paz"

Tu sabes, grande filho, que é incerto

O fim da guerra; porém isto é certo

\footnotetext{
82 SHAKESPEARE, William. op. cit., p. 1.235-1.236.

83 SHAKESPEARE, William. op. cit., p. 1.237.

${ }_{84}$ SHAKESPEARE, William. op. cit., p. 1.249.

85 SHAKESPEARE, William. op. cit., p. 1.252.
} 
Se vences Roma o lucro que assim colhes

Será um nome para sempre maldito.

Numa cena forte, em termos emocionais, vemos a fragilidade e a dependência de Coriolano em relação a sua mãe, que constrói uma eficiente relação de poder com seu filho. O homem violento colapsa e transforma-se num menino frágil, em poucos minutos. De joelhos, expondo uma comunicação submissa, ele tem a seletividade de sua ação controlada, atende ao pedido de paz e diz que não vai mais atacar Roma. O povo está revoltado com os tribunos, mas, com o perdão de Caio Márcio, eles devem revogar o banimento e recebem Volúmnia com honrarias. De certa forma, ele antevê o seu destino trágico e mortal.

\section{CORIOLANO}

Mãe, ó mãe!

O que fez? Veja como os céus se abrem,

E os Deuses, vendo esse quadro anormal,

Se riem dele. Ai, mãe, ai minha mãe!

Para Roma conquistou bela vitória;

Mas sobre o seu filho, creia, creia,

Prevaleceu só com grande perigo,

Ou talvez morte para ele. Que venha.

Aufidio, sem poder fazer mais guerra,

Eu quero elaborar paz conveniente.

Em meu lugar, bom Aufidio, ouviria

Menos sua mãe? Concederia menos?

Na última cena, Coriolano acredita que há alguma chance da paz firmada ser vista como benéfica, mas é recebido como sendo um "traidor", que abusou de seus poderes por desconfirmar o pacto de guerra. Aufídio, em contrapartida, desconfirma seu ato de paz e o seu título de Coriolano ao se referir a ele como Caio Márcio. Também se refere a ele como "guri chorão", despertando a ira do general. Shakespeare mostra o dissenso social presente na época, dentro e fora de Roma. O povo de Corioli avança sobre ele e quer cortá-lo em pedaços. ${ }^{86} \mathrm{O}$ nobre pede que a carnificina pare, e Coriolano faz a desconfirmação violenta final do povo de Corioli e de Aufídio. Os conspiradores puxam as espadas e matam Márcio. Aufídio pisa o corpo, num ato de desconfirmação radical.

$\overline{86}$ SHAKESPEARE, William. op. cit., p. 1.252. 
A violência final está institucionalizada e a relação de poder entre Coriolano e povo de Corioli extinta.

\section{AUFÍDIO}

Não o leiam nobre;

Mas digam ao traidor até que ponto

Abusou de seus poderes.

\section{CORIOLANO}

Traidor? Como?

\section{AUFÍDIO}

Sim traidor, Márcio!

Sim, Márcio, Caio Márcio! Ainda pense

Que lhe concedo o nome que furtou,

Coriolano em Corioli?

Nobre e representantes, com perfídia

Traiu-nos ele a causa concedendo

Por uns pingos salgados, a sua Roma,

Sim, digo "sua”, a sua esposa e mãe;

Quebrando jura e planos como se fossem

Um nó de seda podre, sem consulta

Ao conselho da guerra: só por prantos

Ele entregou, aos gritos, sua vitória,

Envergonhando os pajens e deixando

Os homens espantados, se entreolhando.

\section{CORIOLANO}

Ouviste, Marte?

\section{AUFÍDIO}

Não fale em deuses, guri chorão

\section{CORIOLANO}

Meu coração, nessa mentira imensa,

Explode o que continha. "Guri! “ Crápula!

Perdão senhores, se por vez primeira

Eu precise imprecar. O seu critério

Desmentirá o cão, e a mente dele

Que leva em si as marcas de meus golpes

$E$ há de levar para tumba as minhas surras 
Também o chamará de mentiroso.

TODO O POVO

Cortem logo em pedaços! Já! Agora!

Matou meu filho e filha! Ele matou

Marcos meu primo! Ele matou meu pai!

Na visão de Harold Bloom, Aufídio faz uma leitura apurada da personalidade de Coriolano. Ele é uma vítima notória de sua mãe dominadora, pois se tornou uma criança superprotegida que, exceto no campo de batalha, é um desastre esperando para acontecer em termos sociais. Ao se confrontar com a massa de plebeus, ele os insulta com absoluta fúria. ${ }^{87}$ Nas palavras de Bárbara Heliodora, confirma-se a visão interativa e não substancial do fenômeno do poder:

Ele teve uma educação anômala com Volúmnia, uma mãe viúva, que tentou substituir o pai e acabou dando a seu filho uma visão rígida e bitolada, sem as virtudes mais amenas com que a mãe deve contribuir para a formação equilibrada de um filho. Ele caminha em estado de total ignorância para a sua autodestruição. Ele não sabia ter o comportamento que seu status privilegiado exigia, o direito a esse lugar, por nascimento, não é suficiente. Embora ele fale a partir da sua auto ignorância, ele também tem de ser repelido pelo grupo social. $\mathrm{O}$ ato político que ignora, totalmente, os relacionamentos humanos, peca pela base. ${ }^{88}$

\section{Conclusão}

A associação das teorias pragmáticas da comunicação com a obra shakespeariana evidenciou a presença de interações de poder político em crise de legitimidade, em vários níveis, que nos permitem distinguir o papel da violência e do poder em termos político-jurídicos. Por meio do drama de Coriolano, vivenciamos, em termos afetivos e racionais, como a violência física total pode ser eficiente na guerra e para a afirmação da desigualdade forte/fraco, mas, na política, ela deve ser usada de forma comedida, como alternativa a evitar, ganhando prevalência o uso persuasivo da violência simbólica discursiva. Neste sentido, o destino trágico de Coriolano está associado com a educação materna que inculcou a sua visão unilateral do poder como objeto e sua incapacidade para construir uma interação de poder com os plebeus, que

87 BLOOM, Harold. The invention of the human. New York: Riverhead Books, 1999. p. 578.

88 HELIODORA, Bárbara. Falando de Shakespeare. São Paulo: Perspectiva, 2001. p. 164. 
é totalmente fracassada nas duas tentativas de obter a confirmação popular e acaba por se transformar numa comunicação normativa abusiva, ao identificar sinceridade com grosseria violenta. Ele traz a violência dos campos de batalha para a política, aumentando a crise de legitimidade, pois a violência por si só é incapaz de definir as relações metacomplementares normativas.

Ao fazermos uma leitura detalhada das complexas relações de poder presentes na peça, observamos que ela mostra situações de rupturas permanentes, pois tanto os Vólcios, a plebe, os tribunos e o próprio Coriolano desconfirmam uns aos outros e estão em disputa pela afirmação de relações complementares de autoridade com o objetivo de institucionalizar qual delas seria metacomplementar. Neste trajeto, comunicações normativas abusivas aparecem de forma recíproca, na disputa dramática pelo poder, dentro e fora de Roma. Volúmnia, Menênio e os tribunos da plebe, Brutus e Sicínio, revelam-se hábeis na manipulação, no controle da seletividade e na afirmação da ideia de violência simbólica como elemento constitutivo do poder. Em contrapartida, Coriolano apresenta ter algo em comum com o povo que tanto despreza. Ele é incapaz de exercer uma posição ativa neste controle da seletividade. Ao mesmo tempo em que, de forma superior, alega ser o povo infantil, inconstante e sujeito à manipulação dos tribunos, não percebe que ele também o é, pois a emotividade de ambos suplanta a sua reflexão racional. $\mathrm{O}$ uso estratégico do adjetivo "traidor", pelos tribunos, leva Coriolano a sua ruína no momento em que está em vias de obter a confirmação popular de sua autoridade como cônsul. A falta de consciência sobre o eventual uso destrutivo das emoções, quando estas não estão em equilíbrio com a racionalidade, iguala, de forma, surpreendente Coriolano e os plebeus.

A fala violenta e sincera do protagonista e sua incapacidade em controlá-la, racionalmente, é sua a recusa ao uso ativo e dissimulado da violência simbólica e da visão interativa do poder, mas isto não o impede de ser um agente passivo desta manipulação, feita pelos tribunos e por sua mãe. Na peça, ela desempenha um papel ambíguo, pois, ao mesmo tempo em que denuncia o lado hipócrita do poder, o coloca diante de comunicações abusivas, que generalizam as reações desconfirmadoras, chagando ao limite da guerra. Volúmnia mostra ter o controle total de sua seletividade, em termos pessoais, mesmo em escolhas que contrariam o seu caráter agressivo. No sentido proposto por Edgard Morin, vemos que a consciência subjetiva de Coriolano é bastante complexa, todo o vigor físico superior sucumbe a um pedido da mãe, que ele atende de joelhos, de forma bastante submissa. Ao atender ao pedido materno de paz, contrariando a sua natureza bélica, paradoxalmente, não consegue sair do ciclo pragmático de violência, pois a paz mais uma vez caracteriza, do ponto de vista dos Vólcios, um ato abusivo e desconfirmador que o dirige para a morte, na condição ilícita de traidor.

São Paulo, 30 de maio de 2014. 


\section{Referências}

ARNOLD. Thurman W. El derecho como simbolismo. In: ALBERT, Vilhelm (Org.). Sociología del Derecho. Trad. Esp. J. V. Roberts. Caracas: Tiempo Nuevo, 1971.

BATE, Jonathan. The Genius of Shakespeare. London: Picador, 1997.

BAUMAN, Zigmunt. Medo líquido. Rio de Janeiro: Zahar, 2008.

BLOOM, Harold. The invention of the human. New York: Riverhead Books, 1999.

CANETTI, Elias. Massa e poder. Brasília: Editora Universidade de Brasília, 1983.

CURRY, Julian. Shakespeare on stage, thirteen leading actors on thirteen key roles. London: Nick Hern Books Limited. 2010.

FERRAZ JR. Tercio Sampaio. Introdução ao estudo do direito: técnica, decisão, dominação. 4. ed. São Paulo: Atlas, 2003.

. Direito, retórica e comunicação: subsídios para uma pragmática do discurso jurídico. São Paulo: Saraiva, 1973.

. Teoria da norma jurídica: ensaio de pragmática da comunicação normativa. Rio de Janeiro: Forense, 1978.

. Notas sobre poder e comunicação. Revista Brasileira de Filosofia, São Paulo, v. 34, n. 140, p. 333-356, out./dez., 1985.

. Estudos de filosofia do direito: reflexões sobre o poder, a liberdade a justiça e o direito. São Paulo: Atlas, 2002.

HELIODORA, Bárbara. A expressão dramática do homem político em Shakespeare. Rio de Janeiro: Paz e Terra, 1978.

. Falando de Shakespeare. São Paulo: Perspectiva, 2001.

JAPIASSU, Hilton. Interdisciplinaridade e patologia do saber. Rio de Janeiro: Imago Editora, 1976.

LUHMANN, Niklas. Poder. Brasília: Universidade de Brasília, 1985.

MARCUSE, Herbert. A noção de progresso à luz da psicanálise. In: MARCUSE, Herbert. Cultura e psicanálise. Tradução de Wolfgang Leo Maar, Robespierre de Oliveira e Isabel Loureiro. Rio de Janeiro: Paz e Terra, 2004.

MORIN, Edgar. A cabeça bem feita, repensar a reforma, repensar o pensamento. Rio de Janeiro: Bertrand Brasil, 2000.

OLIVEIRA, Mara Regina de. O desafio à autoridade da lei: a relação existente entre poder, obediência e subversão. Rio de Janeiro: Corifeu, 2006. 
OLIVEIRA, Mara Regina de. Shakespeare e a filosofia do direito: um diálogo com a tragédia Júlio César. Rio de Janeiro: Corifeu, 2006.

SHAKESPEARE, William. Coriolano. In: SHAKESPEARE, William. Teatro completo: tragédias e comédias sombrias. Tradução Bárbara Heliodora. Rio de Janeiro: Nova Aguilar, 2006. v. 1. 